\title{
Review
}

\section{Minerals and Cancer: Overview of the Possible Diagnostic Value}

\author{
Sascha Venturelli ${ }^{1,2}$, Christian Leischner ${ }^{1}$, Thomas Helling ${ }^{1}$, Olga Renner ${ }^{1}$, Markus Burkard ${ }^{1, *}$ \\ and Luigi Marongiu $1, *$ (i)
}

check for updates

Citation: Venturelli, S.; Leischner, C.; Helling, T.; Renner, O.; Burkard, M.; Marongiu, L. Minerals and Cancer: Overview of the Possible Diagnostic Value. Cancers 2022, 14, 1256.

https://doi.org/10.3390/

cancers14051256

Academic Editors: Raffaele Capasso, Carla Cirillo and Paola Amero

Received: 1 February 2022

Accepted: 26 February 2022

Published: 28 February 2022

Publisher's Note: MDPI stays neutral with regard to jurisdictional claims in published maps and institutional affiliations.

Copyright: (C) 2022 by the authors. Licensee MDPI, Basel, Switzerland This article is an open access article distributed under the terms and conditions of the Creative Commons Attribution (CC BY) license (https:// creativecommons.org/licenses/by/ $4.0 /)$.
1 Department of Nutritional Biochemistry, Institute of Nutritional Sciences, University of Hohenheim, Garbenstraße 30, 70599 Stuttgart, Germany; sascha.venturelli@uni-hohenheim.de (S.V.); christian.leischner@uni-hohenheim.de (C.L.); thomas.helling@uni-hohenheim.de (T.H.); olga.renner@uni-hohenheim.de (O.R.)

2 Department of Vegetative and Clinical Physiology, Institute of Physiology, University of Tuebingen, Wilhelmstraße 56, 72074 Tuebingen, Germany

* Correspondence: markus.burkard@uni-hohenheim.de (M.B.); luigi.marongiu@uni-hohenheim.de (L.M.); Tel.: +49-711-459-23621 (M.B.); +49-711-459-23618 (L.M.)

Simple Summary: Minerals are important but often overlooked compounds that are required for a variety of cellular biochemical processes and pathways that regulate cell proliferation. Their dietary imbalance, which is becoming more common in the diets of industrialized countries, is linked to an increased risk of cancer. The current review will present some of the most important minerals for human physiology and evaluate their potential application as cancer biomarkers.

\begin{abstract}
Cancer is the second leading cause of death worldwide and is expected to increase by one-third over the next two decades, in parallel with the growing proportion of the elderly population. Treatment and control of cancer incidence is a global issue. Since there is no clear way to prevent or cure this deadly malignancy, diagnostic, predictive, and prognostic markers for oncological diseases are of great therapeutic value. Minerals and trace elements are important micronutrients for normal physiological function of the body. They are abundant in natural food sources and are regularly included in dietary supplements whereas highly processed industrial food often contains reduced or altered amounts of them. In modern society, the daily intake, storage pools, and homeostasis of these micronutrients are dependent on certain dietary habits and can be thrown out of balance by malignancies. The current work summarizes the data on minerals and trace elements associated with abnormal accumulation or depletion states in tumor patients and discusses their value as potential tumor-associated biomarkers that could be introduced into cancer therapy.
\end{abstract}

Keywords: cancer; biomarkers; minerals; copper; zinc; selenium; iron; iodine; phosphorus; calcium

\section{Introduction}

After World War Two, the mean food intake increased drastically, reflected in an ongoing obesity epidemic [1,2]. On the other hand, the quality of the food did not. Specifically, there has been a decrease in several minerals in foods over the last five decades, most notably zinc, copper, and iron [3-5]. Such an occurrence is mirrored in the worldwide spread of "hidden hunger", defined as a prolonged lack of vitamins or minerals (collectively referred to as micronutrients) intake [6,7]. For example, it has been estimated that the daily intake of selenium is half that of the reference nutrient intake [8].

Micronutrients are necessary for immunological functions as well as the general cellular metabolism [9]. For instance, it has been shown that deficiency in micronutrients, including minerals, worsens the pathogenesis of COVID-19 [10]. Moreover, given the link between an abnormal immune system and oncogenesis [11], identifying factors that affect the former can aid in predicting the latter. Quantification of biomolecules that can interfere 
with immune function, for example, could theoretically serve as an indicator for cancer risk. Micronutrients in general and minerals in particular are suitable for this purpose.

Given that the cellular biochemistry requires micronutrients, the ongoing and unnoticed subclinical deficiency of micronutrients might cause significant global health issues. In particular, the hidden hunger might increase the risk of cancer development. Consequently, the measurement of micronutrients in general and minerals in particular might help the early identification of people at higher cancer risk.

The present work aimed at addressing the potential of selected minerals as potential cancer biomarkers. This review will first highlight the major molecular mechanisms linking minerals to oncogenesis, followed by a report on clinical evidence relating mineral levels to cancer risk, with a focus on the most recent findings.

The recommended daily intake and associated serum levels of the most common minerals are summarized in Table 1 and serve as the basis for the categorization of these in the research cited here. Hence, this review focuses on the possible role of minerals as diagnostic markers for cancer providing an overview of the different molecular pathways that link these micronutrients to the oncogenic process. Figure 1 summarizes the findings of the present work.

Table 1. Recommended daily intakes and related serum levels of the minerals reported in the present review *.

\begin{tabular}{|c|c|c|c|c|c|c|}
\hline Mineral & $\begin{array}{l}\text { RDA/PRI } \\
\text { ( } \mu \text { g/Day) }\end{array}$ & $\begin{array}{l}\text { EAR/AR } \\
\text { ( } \mu \text { g/Day) }\end{array}$ & $\begin{array}{c}\text { UL } \\
\text { ( } \mu \text { g/Day) }\end{array}$ & Serum Levels & Source & References \\
\hline Iron & 8000 & 6000 & 45,000 & $30 \mu \mathrm{g} / \mathrm{L}^{+}$ & $\begin{array}{l}\text { Meat, fish, cereals, } \\
\text { beans, nuts. }\end{array}$ & [12-14] \\
\hline Zinc & $8000-11,000$ & 9400 & 25,000 & $\geq 800 \mu \mathrm{g} / \mathrm{L} \ddagger$ & $\begin{array}{l}\text { Meat, legumes, eggs, } \\
\text { fish, grains. }\end{array}$ & {$[12,15,16]$} \\
\hline Selenium & $30-70$ & 70 & 300 & $47-145 \mu \mathrm{g} / \mathrm{L}$ & Meat, fish. & {$[12,17]$} \\
\hline Phosphorus & 700,000 & 580,000 & n.d. & $0.8-1.5 \times 10^{3} \mu \mathrm{mol} / \mathrm{L}$ & Meat, fish. & {$[12,18]$} \\
\hline Calcium & $1,000,000$ & 750,000 & $2,500,000$ & $2500 \mu \mathrm{mol} / \mathrm{L}$ & Milk, fish, legumes. & {$[12,14,19]$} \\
\hline Copper & 900 & 1600 & 5000 & $1200 \mu \mathrm{g} / \mathrm{L}$ & $\begin{array}{c}\text { Milk, fish, } \\
\text { eggs, vegetables. }\end{array}$ & {$[12,20]$} \\
\hline Iodine & 150 & 95 & 600 & $40-80 \mu \mathrm{g} / \mathrm{L}$ & $\begin{array}{l}\text { Marine products, eggs, } \\
\text { milk, iodized salt. }\end{array}$ & {$[12,21]$} \\
\hline
\end{tabular}

* Depicted data refers to male adults. AR: average requirement; EAR: estimated average requirement; n.d.: not determined by EFSA; PRI: population reference intake; RDA: recommended daily allowance; UL: tolerable upper intake level. ${ }^{\dagger}$ as ferritin. ${ }^{\ddagger}$ not reliable indicator for zinc status. 


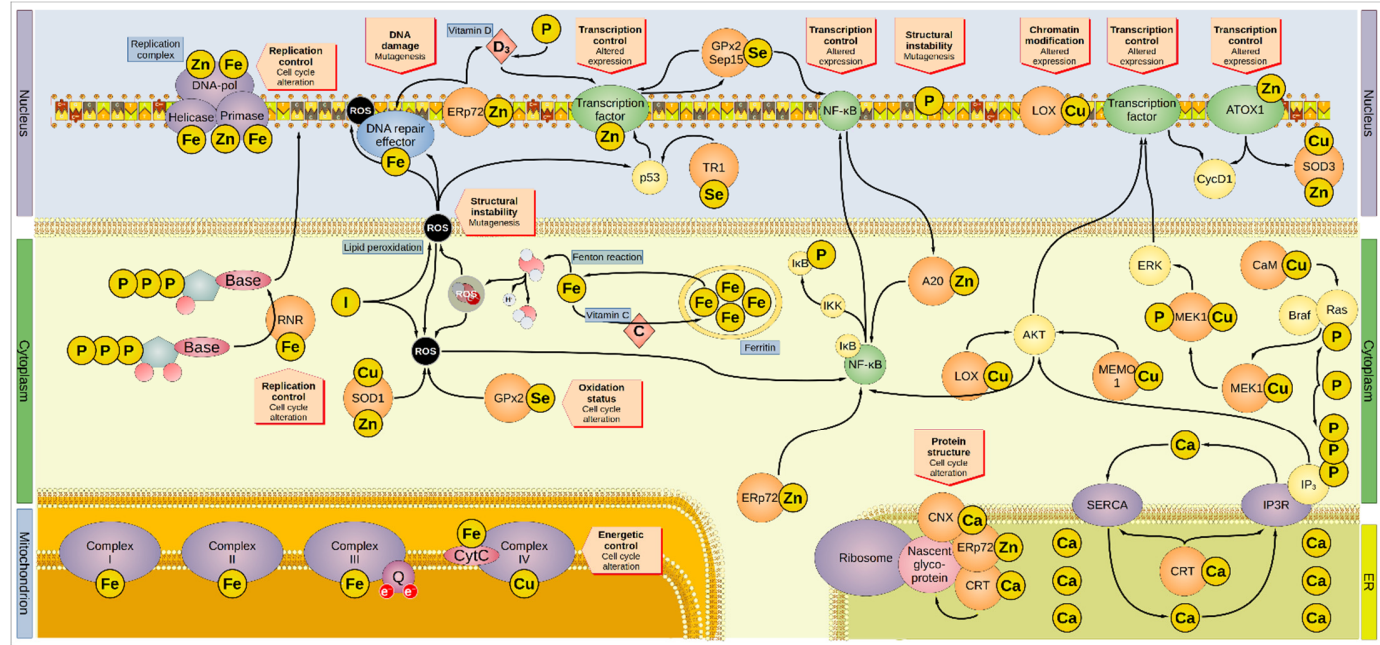

Figure 1. Overview of the involvement of minerals in oncogenesis. Minerals are involved in several and overlapping cellular pathways. Iron is sequestered by ferritin inside the cytoplasm. Iron leaking from the ferritin cages can react with water to form hydroxyl radical, one of the many ROS. Vitamin C promotes the reload of iron inside the ferritin cages. ROS can interact with lipid bilayers, generating more ROS molecules by lipid peroxidation, a process inhibited by iodide. In addition, ROS can directly damage the DNA and proteins, including the DNA-repair enzymes that are activated by ROS-induced damage. Furthermore, ROS activates p53 and NF- $\mathrm{BB}$, altering the cell cycle. Iodide, SOD1, and GPx2 inactivate ROS. For instance, SOD1 removes superoxide radicals by dismutation reaction generating $\mathrm{H}_{2} \mathrm{O}_{2}, \mathrm{O}_{2}$, and GPx2 by producing two $\mathrm{H}_{2} \mathrm{O}$ from auto-reduction. The DNA-repair factors are modulated by the zinc-protein ERp72, which regulates the intake of vitamin D involved in the regulation of transcriptional factors. Cellular intake of vitamin D is also regulated by phosphorus. ERp72 reduces disulfide bonds in nascent proteins in the ER, in association with the calcium-proteins CNX and CRT. Moreover, ERp72 regulates NF-KB, the latter being also modulated by GPx2 and Sep15. GPx2 and Sep15 promote their own expression. A20 and AKT also activate NF- $\mathrm{BB}$, which then reduces the activity of A20 in a negative feedback loop. AKT is modulated by LOX, MEMO1, and IP3, and affects the cell cycle by promoting the expression of $\mathrm{CycD} 1$. LOX can alter genetic expression by modifying the histones. Some transcription factors contain zinc, and a transcription regulator is p53, which TR1 modulates. ATOX1 is a zinccontaining protein that can modulate gene expression, particularly that of cyclin D1 and SOD3 (which regulates the oxidative environment outside the cell). Genetic transcription and cell cycle are regulated by ERK, which MEK1 activates after being phosphorylated by the complex Ras/Braf. One of the modulators of Ras is CaM, but also phosphorus can directly boost its activation. Similarly, phosphorus is also part of active IP3 that, aside from its direct modulation of AKT, regulates the release of calcium (effectively a second messenger on its own right) from the ER via the $\mathrm{Ca}^{2+}$ channel IP3R. The P-type ATPase SERCA mediates the transport of cytosolic calcium back into the ER. CRT regulates both IP3R and SERCA. Moreover, minerals are involved in DNA replication since they are embedded in several subunits of the DNA replication complex (namely: iron in the helicase, primase, and DNA-polymerase $\alpha$, the latter two also containing zinc). Iron is present in the first three mitochondrial complexes and CytC, whereas copper is present in complex IV. Thus, minerals are essential to the energetic balance of the cell and its oxidative state. AKT, Ak strain transforming; A20, zinc finger protein A20; ATOX1, antioxidant-1; Braf, rapidly accelerated fibrosarcoma isoform B; CaM, calmodulin; CNX, calnexin; CRT, calreticulin; CycD1, cyclin D1; CytC, cytochrome c; DNA-pol, DNA polymerase; ER, endoplasmic reticulum; Erp72, endoplasmic reticulum resident protein 72; ERK, extracellular signal-regulated kinase; GPx2, glutathione peroxidase 2; IкB, NF-кB inhibitor; IKK, IкB kinase; IP3, inositol 1,4,5-trisphosphate; IP3R, inositol trisphosphate receptor; LOX, lysyl oxidase; MAPK, mitogen-activated protein kinase; MEK1, MAPK/ERK kinase1; MEMO1, mediator of cell motility 1 ; NF- $\mathrm{kB}$, nuclear factor kappa-light-chain-enhancer of activated $\mathrm{B}$ cells; Q, coenzyme Q; Ras, rat sarcoma virus; RNR, ribonucleotide reductase; ROS, reactive oxygen species; Sep15, selenoprotein of 15-kDa; SERCA, sarco-/endoplasmic reticulum calcium ATPase; SOD, superoxide dismutase; TR1, thioredoxin reductase 1. 


\section{Copper and Zinc}

Copper plays a fundamental role in the oxidation reactions; thus, it is part of many enzymes like mono- and dioxygenases, dehydrogenases, oxidases, and reductases [22]. $\mathrm{Cu}$ transporter 1 (CTR1) transports dietary copper as $\mathrm{Cu}^{+}$into epithelial cells of the small intestine, from where it is then transferred by ATPase copper transporter 7A (ATP7A) to the portal vein and finally released into the bloodstream from liver hepatocytes via ATP7B [23]. Genetic mutations affecting ATP7A result in Menkes disease (MD), a congenital condition characterized by the enterocytes' inability to release copper in the portal vein and generalized copper deficiency. Children affected by MD have limited life expectancy and suffer from growth retardation, osteoporosis, and cellular fibers defects [24]. In the blood, most of the copper is carried in the serum bound to ceruloplasmin and in minor amounts associated with albumin and transcuprein. Hepatocytes accumulate copper, which is subsequently either transported to other cells through the bloodstream or expelled in the bile. Copper is uptaken by the CTR1 on the surface of the cells and stored associated with metallothioneins [25]. Inhibition of the CTR1-copper axis was recently described to diminish AKT signaling and therefore tumorigenesis [26]. Since several studies have reported increased levels of serum or tissue copper in cancer patients than healthy controls, copper has gained interest for therapeutic purposes [27]. Chelators that lower cellular copper bioavailability or ionophores that increase cellular copper bioavailability, respectively, are promising compounds for cancer treatment [23]. Its potential as a drug candidate for cancer therapy when present in a suitable complex was hypothesized to be due to formation free radicals. However, the unfavorable solubility in physiological buffer systems and the sometimes difficult-to-predict mechanism of action pose problems [28]. The concentrations of copper and zinc are tightly bound, and an increased $\mathrm{Cu} / \mathrm{Zn}$ ratio has been observed in a plethora of cancer types [29-34]. Copper cellular concentration is regulated, among others, by mouse U2af1-rs1 region 1 protein (MURR1), which is targeted for ubiquitination by $\mathrm{X}$-linked inhibitor of apoptosis (XIAP) [35,36].

There are about 50 human proteins containing copper, the majority being membrane transporters, that play a major role in metastasis due to their involvement in angiogenesis and cell-to-cell interactions [37-39]. Some of the non-transporter copper-proteins alter the cell cycle at critical points. Lysyl oxidase (LOX), as well as the secreted protein acidic and rich in cysteine (SPARC), mediate the cross-linking of the extra-cellular matrix, actin polymerization, and the activation of the phosphoinositide 3-kinases (PI3K) signaling pathway, thus promoting cellular proliferation and mobility [40,41]. The mediator of cell motility 1 (MEMO1) is also an activator of the PI3K signaling pathway [42]. In addition, LOX might be involved in chromatin remodeling by chemically modifying histones [43]. The mitogen-activated protein kinase kinase 1 (MAPKK, also known as MEK1 (MAPK/ERK kinase 1). or MAP2K1) activates the mitogen-activated protein-kinase (MAPK) signaling pathway, which is involved in proliferation and metastasis [44-47]. Antioxidant protein 1 (ATOX1) is a transcription factor that increases the expression of cyclin D1 and the extracellular super-oxide dismutase isoform 3 (SOD3) [48-50].

Copper also influences autophagy, a cellular process where dysfunctional biological components generated by reactive oxygen species (ROS) activity are sequestered inside specific vesicles (autophagosomes) to maintain homeostasis [51]. Removing damaged biological molecules from the cellular environment protects the cells from apoptosis with the consequence of effectively extending tumor survival [52]. Copper in particular increases the activity of the Unc-51-like autophagy activating kinase (ULK) complexes 1 and 2, which are involved in autophagosome formation and thus promote cancer proliferation [53,54].

Zinc is structurally embedded into over 300 proteins located in the cytoplasm, mitochondria, Golgi apparatus, and nucleus (e.g., in metalloproteases, histone deacetylases, dehydrogenases, hydrolases, transcription factors, DNA polymerase $\alpha$, primase, etc.) involved not only in gene expression but also in the oxidative status of the cell, thus, their disruption is strongly linked to oncogenesis [55-57]. The association between zinc and cancer is not completely understood, but it is known that this micronutrient is associated 
to both immune response and cellular proliferation. In particular, zinc is involved in the regulation of several actors of the cell signaling pathways including protein kinase $C$, cAMP-dependent protein kinase A, phophodiesterase, and nuclear factor kappa-lightchain-enhancer of activated B cells (NF-KB) [58]. NF- KB is part of the Wingless and Int-1 (Wnt) signal pathway, and the targets of this transcription factor include around 200 genes involved in cell proliferation, metastasis, immune response, and inflammation [59,60]. A20 is a zinc-finger NF- $\mathrm{kB}$ suppressor whose expression is controlled by NF- $\mathrm{kB}$, establishing a negative feedback loop for the Wnt signaling pathway, and it has been described as having both promoting and inhibiting carcinogenic properties [61]. Alteration of zinc levels, therefore, can have substantial consequences in cellular proliferation, inflammatory state, and immune response [62].

Zinc is also contained, together with copper, within the enzymes SOD1 and SOD3, which neutralize ROS [63]. SOD1 is prevalently recovered in the cytoplasm but it is also present in the nucleus and other cellular compartments; SOD3, instead, is present on the extracellular environment [64]. The super-oxide anion $\left(\mathrm{O} 2 \bullet^{-}\right)$, which belongs to $\mathrm{ROS}$, is produced during the biochemical reduction of molecular oxygen, for instance in the mitochondrial electron transport chain $\left(\mathrm{O}_{2}+\mathrm{e}^{-} \rightarrow \mathrm{O}_{2} \bullet^{-}\right)$. ROS can cause damage to virtually all biological species within the cell, including DNA strands, proteins (inclusive of the enzymes involved in the DNA damage repair and DNA replication), and lipidic membranes [65]. The super-oxide anion can react with nitric oxide (NO), which has anti-inflammatory properties, to form peroxynitrite $\left(\mathrm{O}_{2} \bullet^{-}+\mathrm{NO} \bullet \rightarrow \mathrm{ONOO}^{-}\right)$that can damage cellular biomolecules, for instance causing lipid peroxidation, and trigger inflammation [66]. While zinc has a structural function, copper is part of SOD's catalytic site and is involved in the reaction of neutralization of super-oxide anion: $2 \mathrm{O}_{2} \bullet^{-}+2 \mathrm{H}^{+}+\mathrm{Cu}^{2+} \rightarrow \mathrm{H}_{2} \mathrm{O}_{2}+\mathrm{O}_{2}+\mathrm{Cu}^{+}$[64]. Unsurprisingly, alteration in SOD's activity is associated with a wide range of diseases [67].

Furthermore, depletion of dietary zinc has been shown to alter the gut microbiota in terms of species richness and diversity, as well as genetic expression [68]. Since the alteration of the gut microbiota composition is associated with an increased risk of carcinogenesis [69], zinc levels might pinpoint cancer risk.

Analysis of 26 breast cancer tissues by mass spectrometry reported a significantly higher concentration of zinc in tumoral mass (3.5-19.5 parts per million (ppm)) than in the surrounding stroma (0.8-11.4 ppm), with a constant ratio of stroma over cancer zinc levels of $2.9 \pm 1.6$ [70]. A comparison of 27 oral squamous cell carcinoma patients and 86 controls reported a non-significantly increased zinc intake in the former group $(12,851 \mathrm{mg}$ daily) than in the latter $(11,788 \mathrm{mg}$ daily) group (Mann-Whitney $\mathrm{U}$ test $p$-value $=0.136$ ) [71].

A survey of 989 hepatocellular carcinoma (HCC) patients did not show an association between zinc concentration and liver cancer, but copper and the ratio of copper over zinc did. When comparing patients in the upper against the lowest quartiles, the hazard ratio (HR) for overall survival (OS) to cancer was 2.06 (1.36-3.11, test for trends $p$-value $<0.01)$ for copper alone and $1.43(0.99-2.08$, test for trends $p$-value $=0.01)$ for the $\mathrm{Cu} / \mathrm{Zn}$ ratio [72] Blood zinc levels in patients with squamous cell carcinoma of the oral cavity were reduced by approximately half $(t$-test, $p$-value $<0.001)$ compared to healthy controls [73]. Zinc and copper were measured in colorectal cancer (966 cases and 966 matched controls) [29]. High zinc concentration was associated to reduced cancer risk (odds ratio $(\mathrm{OR})=0.65$, $95 \%$ confidence interval (CI): $0.43-0.97$, test for trends $p$-value $=0.07$ ), whereas copper had the inverse trend $(\mathrm{OR}=1.50,95 \% \mathrm{CI}: 1.06-2.13$, test for trends $p$-value $=0.02)$. The ratio of copper over zinc was also associated with higher cancer risk (OR $=1.70,95 \%$ CI: 1.20-2.40, test for trends $p$-value $<0.001$ ).

The mean concentration of copper in pancreatic cancer patients $(n=100)$ was $1432 \mu \mathrm{g} / \mathrm{L}$ compared to the $1098 \mu \mathrm{g} / \mathrm{L}$ observed in the matched control group $(n=100)$, and the comparison of people with copper levels in the highest two quartiles and the lowest indicated a higher risk of cancer in high concentration of this micronutrient $(\mathrm{OR}=4.9$, $p$-value < 0.001) [74]. In particular, the threshold of $1215 \mu \mathrm{g} / \mathrm{L}$ was identified as the level above which cancer increased drastically. 
Blood copper levels in patients with squamous cell carcinoma were about $45.5 \%$ higher ( $t$-test, $p$-value $<0.001)$ compared to healthy controls [73]. Spectroscopic analysis of brain sections reported a significantly higher copper concentration in tumoral masses than in surrounding healthy tissues $\left(0.0079\right.$ and $0.037 \mu \mathrm{g} / \mathrm{cm}^{2}$, respectively; Mann-Whitney U test $p$-value < 0.05) [75]. Conversely, in the same sections, zinc had higher levels in tumoral masses than healthy tissues $\left(0.0403\right.$ and $0.0285 \mu \mathrm{g} / \mathrm{cm}^{2}$, respectively; Mann-Whitney U test $p$-value < 0.05). Others have measured 3.9-9.1 times lower copper levels and 2.4-9.6 times lower zinc levels in the tumoral mass than in the surrounding brain tissues [76]. Copper levels in brain tumor patients were significantly higher than in healthy controls ( $t$-test $p$-value < 0.001) [77].

Copper and zinc were suggested as prognostic markers. A cohort of 175 HCC patients reported that serum levels above $68.3 \mu \mathrm{g} / \mathrm{dL}$ and $81.1 \mu \mathrm{g} / \mathrm{dL}$ for copper and zinc, respectively, allowed to identify patients at increased mortality risk with a sensitivity $78.3 \%$ and $60.4 \%$, and a specificity of $48.1 \%$ and $65.2 \%$ [78]. Combining these two micronutrients as $\mathrm{Cu} / \mathrm{Zn}$ ratio gave a sensitivity of $68.1 \%$ and a specificity $75.5 \%$ for a cut-off set at 0.999 .

\section{Selenium}

Until 1957, selenium was considered a toxin, but studies on liver necrosis in rats revealed the biochemical importance of this element [79]. The effect of selenium on cellular biochemistry is proportional to its concentration. Selenium is an antioxidant at nutritional doses, but an oxidant at high (typically pharmacological) doses [80]. While the latter is used to treat tumors because cancerous cells are more susceptible to the oxidative action of selenium [81], dietary selenium deficiency is expected to rise in the near future [82]. The primary natural source of selenium, chiefly in the inorganic forms of selenate $\left(\mathrm{SeO}_{4}{ }^{2-}\right)$ and selenite $\left(\mathrm{SeO}_{3}{ }^{2-}\right)$, is diet (notably fish and meat), whereas non-natural sources of selenium include air pollution and cigarette smoke [83]. Deficiency in selenium intake can result in cardiomyopathy, degenerative disorders (including Alzheimer's disease), and immunological dysfunctions, whereas chronic exposure to high levels of this element (selenosis) may lead to hair loss, skin rash, fatigue, and irritability $[84,85]$.

The organic form of selenium is principally selenocysteine (Sec) which is incorporated into 25 human genes [86]. The triplet UGA, when present in the context of stem-loop structure known as Sec insertion sequence (SECIS), is recognized by a tRNA initially aminoacylated with serine and later converted to Sec [87]. Selenoproteins are widespread in all living kingdoms, including viruses, and all are oxidoreductases with Sec as the catalytic residue [88]. Thioredoxin reductase 1 (TR1), selenoprotein of $15 \mathrm{kDa}$ (Sep15), and glutathione peroxidase 2 (GPx2) are the most studied members of this family in relation to cancer [89]. The main function of TR1 is maintaining the protein structural stability by keeping exposed cysteine residues in reduced form [90], but TR1 can also activate the tumor suppressor p53 [91]. Its overexpression in cancer tissues and cell lines suggests its involvement in cancer promotion [92]. Sep15 is also involved in maintaining the structural integrity of several proteins [93]. Like TR1, Sep15 is also overexpressed in several cancer types [94] and, although its oncogenic involvement is not clear, it has been suggested that it might be involved in cell cycle regulation and interferon- $\gamma$ mediated inflammation [95]. GPx2 is an antioxidant [89], thus, its imbalance can affect the cellular environment at several levels. In addition, GPx2 is regulated by the Wnt pathway [96]. The link between selenium and DNA damage fostered a widespread interest in the association between selenium concentration and risk of cancer and the administration of selenium as anti-cancer treatment [97].

The levels of selenium were not linked to the development of any type of cancer [98], whereas other studies reported that the median blood selenium was $58.8 \mu \mathrm{g} / \mathrm{L}$ in carcinoma patients compared to $84.7 \mu \mathrm{g} / \mathrm{L}$ of healthy controls [99]. Serum selenium in lung cancer patients $(n=48)$ was higher than in healthy controls $(n=39)$, with values of 166.0 and $144.7 \mathrm{ng}$ per gram of serum, respectively, but the difference was not statistically significant [100]. A comparison of patients with serum selenium in the upper tertile $(77.8 \mu \mathrm{g} / \mathrm{L})$ 
to those in the lower tertile $(50.8 \mu \mathrm{g} / \mathrm{L})$ in a group of 302 patients results in a higher risk of lung cancer $(\mathrm{HR}=1.64,95 \% \mathrm{CI}: 1.14-2.37$, test for trends $p$-value $<0.01)$ [101]. Conversely, serum selenium was lower in renal cancer patients $(161.7 \mu \mathrm{g} / \mathrm{L}, n=104)$ than in healthy controls $(228.8 \mu \mathrm{g} / \mathrm{L}, n=774)$, resulting in an OR of 0.14 (95\% CI: $0.10-0.20$, test for trends $p$-value <0.01) [102].

The amount of selenium in prostate tissues was not significantly different $(p$-value $=0.347)$ between cancer patients $(n=49)$ and healthy controls $(n=49)$, with mean concentrations of 191 and $168 \mu \mathrm{g} / \mathrm{kg}$, respectively [103]. A comparison of prostate cancer cases $(n=467)$ and controls $(n=936)$ showed no statistical association between serum levels of selenium [104]. However, the stratification by ethnicity showed a trend $(p$-value $=0.02)$ for African-Americans, with the OR of the third over the first tertile being 0.59 . Selenium serum levels were, instead, significantly lower in hepatoma patients $(n=187$, mean concentration: $67.47 \mu \mathrm{g} / \mathrm{L})$ than in healthy controls $(n=120$, mean concentration: $108.38 \mu \mathrm{g} / \mathrm{L}$ ) [105]. A study of 966 colorectal cancer cases and 966 matched healthy controls reported no significant differences in serum selenium levels between the two groups ( 84.0 and $85.6 \mu \mathrm{g} / \mathrm{L}$, respectively), but stratification by gender showed a statistically significant decrease in cancer risk in women with the higher concentration of selenium than women with the lowest concentration (incidence rate ratio $=0.83,95 \% \mathrm{CI}$ : $0.70-0.97$, test for trends $p$-value 0.032) [106]. Higher selenium was reported to be significantly higher (univariate ANOVA $p$-value $<0.001$ ) in esophageal tumors than in healthy surrounding tissues [107].

The mean concentration of selenium in pancreatic cancer patients $(n=100)$ was $60 \mu \mathrm{g} / \mathrm{L}$ compared to the $76 \mu \mathrm{g} / \mathrm{L}$ observed in the matched control group $(n=100)$, and the ratio of people with selenium levels in the lower two quartiles and the upper indicated a higher risk of cancer in the presence of depletion of this micronutrient $(\mathrm{OR}=41, p$-value $<0.001)$ [74]. In particular, the threshold of $67 \mu \mathrm{g} / \mathrm{L}$ was identified as the level below which cancer increased drastically. In liver cancer patients, serum selenium $(52.5 \mu \mathrm{g} / \mathrm{L})$ was lower than the average level of healthy controls [108]. Specifically, 93.7\% of the patients had serum levels below the threshold of $70 \mu \mathrm{g} / \mathrm{L}$ indicating dietary deficiency for this micronutrient.

Similarly, in breast cancer, women in the upper quartile of serum selenium concentration had a lower risk of mortality than women in the lowest quartile $(\mathrm{HR}=0.63$, 95\% CI: 0.44-0.89) [109]. Blood selenium levels dropped from $74.3 \mu \mathrm{g} / \mathrm{L}$ in breast cancer patients with tumors smaller than $2 \mathrm{~cm}$ in diameter to $64.8 \mu \mathrm{g} / \mathrm{L}$ in those with tumors larger than $5 \mathrm{~cm}$ in diameter $\left(\chi^{2} p\right.$-value $\left.=0.03\right)$ [110]. In the same study, the ratio of breast cancer patients with serum selenium in the first and fourth quartiles was associated to a higher mortality rate $(\mathrm{HR}=2.03,95 \% \mathrm{CI}: 1.12-3.65$, $p$-value $=0.02)$. Conversely, the comparison of 27 oral squamous cell carcinoma patients and 86 controls reported higher selenium intake in the former $(142.9 \mu \mathrm{g}$ daily) than in the latter (106.7 $\mu \mathrm{g}$ daily) group (Mann-Whitney $\mathrm{U}$ test $p$-value $=0.002)[71]$.

\section{Phosphorus}

Phosphorus is one of the most abundant elements in the human body (after oxygen, hydrogen, carbon, nitrogen, and calcium), accounting for about $1 \%$ of body weight and being stored in the bones as hydroxyapatite $\left(\mathrm{Ca}_{10}\left(\mathrm{PO}_{4}\right)_{6}(\mathrm{OH})_{2}\right)$ [111]. Dietary phosphorus is usually present in organic form (embedded mostly in proteins, nucleic acids, and phospholipids) and requires specific enzymes to be recovered during digestion, hence its adsorption rate has relatively low efficiency [112]. Phosphorus is present in virtually all types of food [113], thus, even if deficiency of this mineral has been described and was associated with a series of diseases, chiefly bone demineralization and myopathy, it is hyperphosphatemia that is relevant in developed countries [114]. In particular, inorganic phosphorus, in the form of phosphoric acid $\left(\mathrm{H}_{3} \mathrm{PO}_{4}\right)$ is a common additive in soft drinks and foodstuff and it is rapidly absorbed with approximately $100 \%$ efficiency $[112,115,116]$. The addition of phosphates to processed foods and canned drinks almost doubles the daily intake of phosphorus $[112,117,118]$. Excess dietary phosphorus is linked to arteriosclerosis, renal dysfunction, premature aging, and cancer [119]. Intake of phosphorus is complicated by the fact that it is entangled with that of calcium and vitamin D, whose imbalance is also 
associated with an increased risk of cancer [120]. Moreover, even dietary fructose acts as an additional bias because it decreases the intestinal adsorption of phosphate [121].

Vitamin D, in the active form of calcitriol, increases intestinal phosphate absorption while decreasing renal excretion, thereby increasing phosphorus serum levels, whereas hyperphosphatemia decreases calcitriol serum levels [122]. Calcium, on the other hand, chelates phosphates, thus reducing the serum levels of phosphorus [123]. The interrelation between calcitriol and phosphate generates a feedback mechanism that maintains the homeostasis of phosphorus in the human body, but chronic hyperphosphatemia determines the obliteration of the protective role of vitamin D, increasing the risk of cancer [123]. Vitamin D could reduce the insurgence of dysbiosis, reducing the risk of developing colon cancer [124]. Interestingly, patients of different cancer types showed consistent hyperphosphatemia [125] and cancer cells derived from several tissue types showed high cellular levels of phosphate [126].

Experiments on mice showed that high phosphorus intake increases the risk of lung cancer by activating the PI3K signaling pathway [127], whereas studies on cell lines showed that phosphate can directly activate the protein kinase B (Ak strain transforming (AKT)) [128]. The aberrant activation of the inositol 1,4,5-trisphosphate (IP3)/AKT signaling pathway due to excess phosphate in the cells can explain the association of hyperphosphatemia with several types of cancer [117]. Another role associated with high increase in phosphorus intake is the fact that phosphate makes insoluble complexes with calcium, depleting this mineral from binding bile acids known to foster bacteriosis and oncogenesis [129-131].

Spectroscopic analysis of brain sections reported a significantly lower phosphorus concentration in tumoral masses than in surrounding healthy tissues $\left(1.71\right.$ and $3.01 \mu \mathrm{g} / \mathrm{cm}^{2}$, respectively; Mann-Whitney U test $p$-value $<0.05$ ) [75].

Comparison of men $(n=4123)$ in the upper over the lower quintile of the phosphorus dietary intake showed a non-significant risk of prostate cancer (relative risk $(R R)=1.1$, $95 \%$ CI: 0.7-1.8, test for trends $=0.45$ ) [132]. Quantification of micronutrients in the diet in a group of 6403 volunteers did not find a significant linear relation between phosphorus intake and concentration of serum prostate specific antigen, but there was a non-linear relationship due to an inflection point at a daily intake of $1151 \mathrm{mg}$ [133]. A comparison of 27 oral squamous cell carcinoma patients and 86 controls reported an increased intake of phosphorus in the former (1761 $\mathrm{mg}$ daily) than in the latter (1431 $\mathrm{mg}$ daily) group (Mann-Whitney U test $p$-value $=0.003$ ) [71].

Comparison of the upper and the lower quartiles in 516 cases of colorectal adenomas indicated a decreased risk of the insurgence of neoplasm (RR $=0.70,95 \% \mathrm{CI}$ : $0.54-0.90$, test for trends $p$-value $=0.005)$ [134]. Such a trend was not observed in the 172 colorectal cancer-associated cases in the same study $(R R=0.73,95 \%$ CI: $0.48-1.10$, test for trends $p$-value $=0.11$ ). There was a slightly non-significant higher risk of bladder cancer when comparing cases in the upper over the lower tertiles of daily phosphorus intake $(\mathrm{OR}=1.82$, $95 \%$ CI: $0.95-3.49$, test for trends $p$-value $=0.06$ ) [135]. When comparing cases in the upper over the lower quintiles of daily phosphorus intake, there was a non-significant higher risk of prostate cancer $(\mathrm{OR}=1.20,95 \%$ CI: $0.79-1.84$, test for trends $p$-value $=0.39)$ [136]. There was an increased relative risk of prostate cancer when comparing patients in the upper over the lowest quintiles of daily phosphorus intake ( $R R=1.12,95 \%$ CI: $1.03-1.23$, test for trends, $p$-value $=0.003)$ in a cohort of 19147 patients [137].

\section{Iron and Iodine}

Iron, like copper, is fundamental for cellular biochemistry due to its oxidoreductase properties [138]. In particular, the link between cancer and iron is due to its involvement in the oxidative status of the cell [65]. The bulk of dietary iron is absorbed in the duodenum, whereas a large proportion of iron for human physiology is derived by recycling old erythrocytes [139]. The iron found in fruits, vegetables, nuts, grains, and the majority of meat is ferric $\left(\mathrm{Fe}^{3+}\right)$ and not associated with the heme group, whereas approximately 
$40 \%$ of meat-derived iron is part of the metalloporphyrin complex. Ferric iron is converted to ferrous iron $\left(\mathrm{Fe}^{2+}\right)$ by the duodenal cytochrome $\mathrm{B}$ reductase and transported by divalent metal transporter 1 (DMT-1) inside intestinal epithelial cells (enterocytes), whereas, an independent process internalizes the heme group, which contains ferrous iron [140]. Colonocytes are less efficient in heme uptake than enterocytes because they express less DMT-1; as a result, these cells normally have low iron content. The meat-rich Western diet has been associated with a daily intake of about $15 \mathrm{mg}$ of iron (10\% of it actually being absorbed by the enterocytes) and has increased colorectal carcinoma (CRC) risk [138,141]. Vitamin C increases enterocytes heme-iron intake while calcium decreases it [142-144]. Ferrous iron is trapped inside proteinaceous shells made of ferritin, forming molecular cages capable of holding up to 5000 iron atoms [145]. Iron is released into the bloodstream by the enterocytes via ferroportin, where it is converted to ferric form and bound to plasma transferrin [140]. The amount of serum iron is regulated by modulating the expression of ferroportin and hepcidin; the latter binds ferroportin causing the degradation of this membrane transporter [140]. Excess serum iron is deposited in several organs including liver, pancreas, and heart causing several diseases such as cirrhosis, cardiomyopathy, diabetes, and cancer. The oncogenesis of CRC and HCC has been linked to excess cellular iron and the process is the same in the two tissues [146]. In animal models, a diet high in red meat has been shown to increase the amount of heme in the colon, leading to an increase in the frequency and size of colorectal polyps $[143,147,148]$. Colonocytes will be used to describe the oncogenic process linked to iron.

The amount of iron inside cells is tightly regulated, and oncogenesis associated with this micronutrient is caused by high levels of a powerful oxidoreductive species in the cellular environment. Through the Fenton reaction $\left(\mathrm{Fe}^{2+}+\mathrm{H}_{2} \mathrm{O}_{2}+\mathrm{H}^{+} \rightarrow \mathrm{Fe}^{3+}+\mathrm{H}_{2} \mathrm{O}+\mathrm{HO} \bullet\right.$ ), iron can produce hydroxyl radical $(\mathrm{HO} \bullet$ ) that belongs to ROS. Lipid peroxidation, in particular, will increase the number of radicals within the cell, alter cellular permeability, and initiate an inflammatory response [149]. Vitamin C, in the form of ascorbate $\left(\mathrm{AscH}^{-}\right)$rescues leaked ferrous iron by converting ferric iron to $\mathrm{Fe}^{2+}$, which can be taken up by ferritin, but in the presence of a large amount of iron, it boosts the Fenton reaction by providing even more ferrous iron: $\mathrm{Fe}^{3+}+\mathrm{AscH}^{-} \rightarrow \mathrm{Fe}^{2+}+\mathrm{H}^{+}+\mathrm{Asc}^{-}$[150]. The ascorbic radical $\left(\mathrm{Asc}^{-}\right)$can also affect the mitochondrial respiration producing a ROS burst that causes even further cellular damage [120]. ROS is also part of several signal pathways (such as NF- $\kappa$ B, PI3K, and MAPK), hence, high levels of these free radicals promote aberration in cellular proliferation and inflammation [151,152]. Iron is also included in the catalytic centers of the mitochondrial complexes I (nicotinamide adenine dinucleotide hydride (NADH) dehydrogenase), II (succinate dehydrogenase), and III (cytochrome bc-1 complex) [153].

It is known that the amount of cellular iron is directly related to the proliferation of the cells [65], due to the fact that iron is part of several enzymes that are involved in the DNA replication (polymerases $\alpha, \varepsilon$, and $\delta$, DNA primase, and helicase) and repair (polymerase $\zeta$, helicase, DNA glycosylase, $\mathrm{Fe}^{2+} / 2$-oxoglutarate-dependent dioxygenase) [154]. Iron is also a component of the ribonucleotide reductase (RNR) enzyme that transforms ribonucleotides to deoxyribonucleotides, without which DNA replication would be impossible $[155,156]$. Moreover, iron can promote cellular proliferation by activating the Wnt signaling pathway in presence of adenomatous polyposis coli (APC) mutations, thus, increasing the CRC risk [157].

Iodine is incorporated primarily in thyroid hormones, whereas its non-hormonal activity is less understood but is believed to be also involved in the oxidative state of the cells [158]. The biological role of iodine in oncogenesis is due to its role as a ROS scavenger and lipoperoxidation inhibitor in the reduced form of iodide $\left(\mathrm{I}^{-}\right)$[159]. The RDA for iodine is $150-299 \mu \mathrm{g}$ daily, and abnormal intake is associated with widespread dysfunctions, including disrupting the immune system.

The risk of developing any cancer was lower in people under a regime of low iron intake $(n=60)$ than in people under regular diet $(n=38)$, with an HR of 0.65 (95\% CI: $0.43-0.97$, test for trends $p$-value $=0.36$ ) [160]. Interestingly, a study on 11026 cancer cases showed 
that the cancer risk increased at high (above $80 \mu \mathrm{g} / \mathrm{dL}$ ) and low (below $60 \mu \mathrm{g} / \mathrm{dL}$ ) serum iron [161]. Low serum iron was associated with an HR of 1.18 (95\% CI: 1.08-1.29), whereas high levels had an HR of 1.25 (95\% CI: 1.16-1.35).

A meta-analysis of the scientific literature reported that high serum iron was associated with a higher risk of colorectal cancer $(\mathrm{RR}=1.02,95 \% \mathrm{CI}$ : $0.75-1.38)$ as was high intake of heme iron ( $R R=0.93,95 \% \mathrm{CI}$ : 0.62-1.42) [162]. Other meta-analysis did not support such trends, indicating an RR of 0.97 (95\% CI: 0.82-1.14) in relation to iron intake [163]. Such disparate findings highlight the paucity of knowledge about the role of iron in oncogenesis and the need for additional research.

Serum iron below $60 \mu \mathrm{g} / \mathrm{dL}$ was associated with more prolonged survival of gastric cancer patients in Stage III (log-rank test $p$-value $=0.033$ ) [164]. A comparison of 27 oral squamous cell carcinoma patients and 86 controls reported an increased iron intake in the former (22.4 mg daily) than in the latter (18.9 $\mathrm{gg}$ daily) group (Mann-Whitney U test $p$-value $=0.029$ ) [71]. The comparison of blood iron in oral squamous-cell carcinoma was significantly higher $(t$-test $p$-value $<0.001)$ than in healthy controls $(194.6$ and $128.6 \mu \mathrm{g} / \mathrm{dL}$, respectively) [73].

A comparison of breast cancer patients $(n=24)$ and healthy volunteers $(n=48)$ showed a higher proportion of cases with urine iodine concentration above $200 \mu \mathrm{g} / \mathrm{L}(33.3 \%)$ compared to the controls $(2.1 \%)\left(\chi^{2}\right.$ test $p$-value $\left.=0.001\right)$ [165]. A study of 5926 breast cancer patients found an HR of 1.06 (95\% CI: 0.90-1.25) when comparing the upper quartile of serum iron to the first quartile, though no significant relationship was found [166]. Measurement of iodine concentration by computed tomography in 80 rectal cancer patients showed a correlation with the marker of cellular Ki-67 (Spearman correlation coefficient $\mathrm{r}=0.344, p$-value $=0.002)$ and the tumor biomarker hypoxia-inducible factor $1 \alpha(\mathrm{HIF}-1 \alpha)$ $(\mathrm{r}=0.598, p$-value $<0.001)$, the latter used at a threshold of $0.584 \mathrm{~g} / \mathrm{cm}^{3}$ to attain a $78 \%$ sensitivity and $87 \%$ specificity in the detection of cancer [167].

Spectroscopic analysis of brain sections reported a significantly lower iron concentration in tumoral masses than in surrounding healthy tissues $\left(0.118\right.$ and $0.088 \mu \mathrm{g} / \mathrm{cm}^{2}$, respectively; Mann-Whitney U test $p$-value <0.01) [75]. When patients in the upper quartile were compared to those in the lower quartile, low iron concentration in urine was associated with a lower risk of developing large thyroid tumors, with an OR of 0.56 (95\% CI: 0.35-0.9, test for trends $p$-value $=0.026$ ) [168].

\section{Calcium}

Calcium is part of many signaling pathways as second messenger and it takes part directly in the cell-to-cell adhesion, hence calcium impairment has a profound effect on the cell cycle, cellular proliferation, resistance to apoptosis, and metastasis $[169,170]$. Calcium is also involved in the folding of proteins synthesized in the endoplasmic reticulum (ER) [171]. In particular, calnexin (CNX) is an enzyme embedded in the ER's membrane that can interact with nascent glycosylated proteins in a calcium-dependent manner [172].

Calcium is stored inside the ER by specific membrane pumps known as sarco/endoplasmic reticulum calcium ATPases (SERCA) and released in the cytoplasm upon stimulation with IP3 by channels known as IP3 receptors (IP3R) [173]. SERCA has been proposed as a tumor biomarker due to the relation between its altered expression and cancer development [174]. Calreticulin (CRT) is present in the ER's lumen and regulates both the intake and release of calcium [175]. Both CNX and CRT has been linked to several diseases including cystic fibrosis, atherosclerosis, Alzeimer's disease, and cancer [171] and both can interact with the zinccontaining endoplasmic reticulum resident protein 72 (ERp72) [176]. ERp72 over-expression is associated to cellular proliferation and has been identified not only as part of the CNX/CRT complex for the maturation of glycoprotein (where it acts as a disulfide isomerase), but is also involved in the rapid internalization and nuclear translocation of vitamin D3 (in the form of calcitriol), the activation of several transcription factors (such as NF- $k \mathrm{~B}$, mammalian target of rapamycin complex 1 (mTORC1), and eukaryotic translation initiation factor $4 \mathrm{E}$ binding protein 1 (4E-BP1)), and DNA repair (by modulating the activity of the redox factor-1 and by 
directly regulating the phosphorylation of histone H1AX) [177]. Moreover, calcium is loaded onto calmodulin (CaM), which binds and modulates not only one member of the Ras family of GTPases, Kirsten rat sarcoma (K-Ras), but many kinases, phosphatases, membrane pumps, transcription factors, and proteins of the extracellular matrix [178,179].

The tissue calcium levels were measured at $1431 \mathrm{mg} / \mathrm{kg}$ in healthy subjects $(n=49)$ and $657 \mathrm{mg} / \mathrm{kg}$ in prostate cancer patients $(n=50)$, with a statistically significant difference ( $p$-values < 0.001) [103]. Serum calcium levels were similar between ovarian cancer patients and healthy controls ( 9.34 and $9.31 \mathrm{mg} / \mathrm{dL}$, respectively) but the normalization by serum albumin content was significantly higher in cases than in controls $(9.95 \mathrm{mg} / \mathrm{dL}$ and $9.53 \mathrm{mg} / \mathrm{dL}$, respectively; $p$-value < 0.01) [180]. High serum calcium levels reduced the risk of breast cancer: the ratio of the fourth over the first quartiles in a group of 10863 patients gave $\mathrm{HR}=0.94(\mathrm{CI}: 0.8-0.99$, test for trends $p$-value $=0.04)$ [181].

The comparison of blood calcium in oral squamous-cell carcinoma was significantly higher $(t$-test $p$-value $<0.001)$ than in healthy controls $(14.7$ and $9.4 \mathrm{mEq} / \mathrm{L}$, respectively) [73]. Spectroscopic analysis of brain sections reported a significantly lower calcium concentration in tumoral masses than in surrounding healthy tissues $(0.088$ and $0.182 \mu \mathrm{g} / \mathrm{cm}^{2}$, respectively; Mann-Whitney U test $p$-value < 0.01) [75].

Calcium levels can also identify patients at higher risk for metastases. However, a cut-off of $2.5 \mathrm{mmol} / \mathrm{L}$ of calcium could identify bone metastases in bladder cancer patients with a sensitivity of $32 \%$ and a specificity of $94 \%$, with high calcium levels providing an increased risk of metastasis (OR $=13.049, \mathrm{CI}$ : 3.836-44.384, $p$-value $<0.001)$ [182]. A cut-off of 2.7 could identify HCC patients at risk of ocular metastasis with a sensitivity of $19 \%$ and a specificity of 97\%, with high calcium levels providing an OR of 1.062 (CI: 1.028-1.096) for the risk of metastasis [183].

\section{Discussion}

Nutrition's role in oncogenesis is increasingly being researched and supported by new scientific data. As a result, scientists are becoming more and more interested in determining the role of micronutrients in DNA stability, epigenetic regulation, immunological response, and in assessing their role as biomarkers.

Tumorigenesis is extremely complex and varies greatly between tumor entities due to the involvement of multiple molecular processes. The present analysis revealed some intriguing tendencies, even though there is no unified trend relating mineral intake and cancer risk. Specifically, higher levels of copper, iron, and iodine were linked to higher cancer risk, but zinc, selenium, calcium, and phosphorus had a more mixed relationship. A higher mineral intake was linked to an increased risk of oral cancer (iron, selenium, phosphorus, and zinc). Higher levels of zinc and copper, but lower levels of selenium, were more associated with liver cancer. Prostate cancer, on the other hand, was associated with higher phosphorus intake. The association between minerals and risk of cancer in observational and intervention studies is summarized in Tables 2-4, respectively.

Table 2. Summary of the association between minerals and risk of cancer in observational studies.

\begin{tabular}{|c|c|c|c|c|c|}
\hline Mineral & Organ & Sample & Association * & Measure $^{\dagger}$ & Reference \\
\hline \multirow[t]{8}{*}{ Zinc } & Breast & Tissue & Direct & $\mathrm{Qt}$ & [70] \\
\hline & Brain & Tissue & Inverse & $\mathrm{Qt}$ & [76] \\
\hline & & Intake & Inverse & $\mathrm{Qt}$ & [75] \\
\hline & Mouth & Intake & None & $\mathrm{Qt}$ & [71] \\
\hline & & Serum & Inverse & $\mathrm{Qt}$ & [73] \\
\hline & Liver & Serum & None & HR & [72] \\
\hline & & Serum & Direct & $\mathrm{Qt}$ & [78] \\
\hline & Colon & Tissue & Inverse & OR & [29] \\
\hline
\end{tabular}


Table 2. Cont.

\begin{tabular}{|c|c|c|c|c|c|}
\hline Mineral & Organ & Sample & Association * & Measure $^{\dagger}$ & Reference \\
\hline \multirow[t]{8}{*}{ Copper } & Liver & Serum & Direct & HR & [72] \\
\hline & & Serum & Direct & $\mathrm{Qt}$ & [78] \\
\hline & Mouth & Serum & Direct & Qt & [73] \\
\hline & Colon & Tissue & Direct & OR & [29] \\
\hline & Brain & Tissue & Inverse & Qt & [76] \\
\hline & & Serum & Direct & $\widehat{\mathrm{Qt}}$ & [77] \\
\hline & & Intake & Inverse & $\mathrm{Qt}$ & [75] \\
\hline & Pancreas & Serum & Direct & $\mathrm{Qt}$ & [74] \\
\hline \multirow[t]{15}{*}{ Selenium } & Esophagus & Tissue & Direct & $\widehat{\mathrm{Q}} \mathrm{t}$ & [107] \\
\hline & Prostate & Tissue & None & $\widehat{Q} t$ & [103] \\
\hline & & Serum & None $\|$ & Qt & [104] \\
\hline & Any & Serum & None & Qt & [98] \\
\hline & & Serum & Inverse & $\widehat{\mathrm{Qt}}$ & [99] \\
\hline & Liver & Serum & Inverse & $\widehat{Q} t$ & [105] \\
\hline & & Serum & Inverse & $\mathrm{Qt}$ & [108] \\
\hline & Colon & Serum & None $\mathbb{I}$ & IR & [106] \\
\hline & Pancreas & Serum & Inverse & OR & [74] \\
\hline & Breast & Serum & Inverse & HR & [109] \\
\hline & & Serum & Inverse & HR & [110] \\
\hline & Lung & Serum & None & Qt & [100] \\
\hline & Lung & Serum & Direct & HR & [101] \\
\hline & Kidney & Serum & Inverse & OR & [102] \\
\hline & Mouth & Intake & Direct & Qt & [71] \\
\hline \multirow[t]{8}{*}{ Phosphorus } & Brain & Intake & Direct & Qt & [75] \\
\hline & Prostate & Intake & None & $\hat{R R}$ & [133] \\
\hline & & Intake & Direct & $\mathrm{Cr}$ & [133] \\
\hline & & Intake & Direct & OR & [137] \\
\hline & & Intake & None & OR & [136] \\
\hline & Colon & Intake & Inverse \# & $\mathrm{RR}$ & [134] \\
\hline & Bladder & Intake & None & OR & [135] \\
\hline & Mouth & Intake & Direct & Qt & [71] \\
\hline \multirow[t]{5}{*}{ Calcium } & Prostate & Tissue & Direct & $\widehat{\mathrm{Qt}}$ & [103] \\
\hline & Brain & Intake & Direct & Qt & [75] \\
\hline & Ovary & Serum & Direct & $\mathrm{Qt}$ & [180] \\
\hline & Breast & Serum & Inverse & $\hat{\mathrm{HR}}$ & [181] \\
\hline & Mouth & Serum & Direct & Qt & [73] \\
\hline \multirow[t]{8}{*}{ Iron } & Any & Serum & Direct/Inverse & HR & [161] \\
\hline & & Intake & Direct & HR & [160] \\
\hline & Stomach & Tissue & Direct & Qt & [164] \\
\hline & Brain & Intake & Direct & $\widehat{Q} t$ & [75] \\
\hline & Mouth & Intake & Direct & $\widehat{\mathrm{Qt}}$ & [71] \\
\hline & & Serum & Direct & $\widehat{Q t}$ & [73] \\
\hline & Breast & Serum & None & HR & [166] \\
\hline & Thyroid & Urine & Direct & OR & [168] \\
\hline \multirow[t]{2}{*}{ Iodine } & Breast & Urine & Direct & Qt & [165] \\
\hline & Rectum & Tissue & Direct & $\mathrm{Cr}$ & [167] \\
\hline
\end{tabular}

* Direct: high micronutrient concentration is linked to an increased risk of cancer; inverse: low micronutrient concentration is linked to an increased risk of cancer; none: no significance observed. ${ }^{\dagger} \mathrm{Cr}$ : correlation; Qt: comparison of levels between groups; HR: hazard ratio; IR: incidence rate ratio; OR: odds ratio; RR: relative risk.

" Observed inverse trend by ethnic stratification. "I Observed inverse trend by sex stratification. ${ }^{\#}$ Observed in adenomas but not in carcinomas. 
Table 3. Summary of the mineral levels in the studies retrieved for the present work.

\begin{tabular}{|c|c|c|c|c|c|}
\hline Mineral & Cancer Entity & Sample & $\begin{array}{l}\text { Case Group (Cancer) } \\
\text { Mean Mineral Content } \\
\text { Number of Patients }\end{array}$ & $\begin{array}{l}\text { Control Group (Healthy) } \\
\text { Mean Mineral Content } \\
\text { Number of Patients }\end{array}$ & Reference \\
\hline \multirow[t]{4}{*}{ Zinc } & Breast & Tissue $^{\dagger}$ & $3.5-19.5$ ppm $(n=26)$ & $0.8-11.4$ ppm $(n=26)$ & {$[70]$} \\
\hline & Glioblastoma & Tissue & $0.0403 \mu \mathrm{g} / \mathrm{cm}^{2}(n=11)$ & $0.0285 \mu \mathrm{g} / \mathrm{cm}^{2}(n=11)$ & [75] \\
\hline & & Tissue $^{+}$ & $0.20 \mathrm{~g} / \mathrm{kg}(n=6)$ & $0.27 \mathrm{~g} / \mathrm{kg}(n=6)$ & [76] \\
\hline & Colon & Serum & $96.4 \mu \mathrm{g} / \mathrm{dL}(n=966)$ & $97.1 \mu \mathrm{g} / \mathrm{dL}(n=966)$ & [29] \\
\hline \multirow[t]{5}{*}{ Copper } & Glioblastoma & Tissue & $0.0090 \mu \mathrm{g} / \mathrm{cm}^{2}(n=11)$ & $0.0079 \mu \mathrm{g} / \mathrm{cm}^{2}(n=11)$ & {$[75]$} \\
\hline & & Tissue $^{+}$ & $0.48 \mathrm{~g} / \mathrm{kg}(n=6)$ & $1.26 \mathrm{~g} / \mathrm{kg}(n=6)$ & [76] \\
\hline & & Serum & $27.5 \mu \mathrm{mol} / \mathrm{L}(n=52) \ddagger$ & $19.7 \mu \mathrm{mol} / \mathrm{L}(n=52) \ddagger$ & [77] \\
\hline & Colon & Serum & $138.6 \mu \mathrm{g} / \mathrm{dL}(n=966)$ & $135.8 \mu \mathrm{g} / \mathrm{dL}(n=966)$ & [29] \\
\hline & Pancreas & Serum & $1432 \mu \mathrm{g} / \mathrm{L}(n=100)$ & $1098 \mu \mathrm{g} / \mathrm{L}(n=100)$ & [74] \\
\hline \multirow[t]{10}{*}{ Selenium } & Any & Serum & $58.8 \mu \mathrm{g} / \mathrm{L}^{*}$ & $84.8 \mu \mathrm{g} / \mathrm{L}(n=966)$ & {$[99,106]$} \\
\hline & Esophageal & Tissue $^{+}$ & $0.73 \mu \mathrm{g} / \mathrm{g}(n=30) \ddagger$ & $0.59 \mu \mathrm{g} / \mathrm{g}(n=30) \ddagger$ & [107] \\
\hline & Prostate & Tissue & $191 \mu \mathrm{g} / \mathrm{kg}(n=49)$ & $168 \mu \mathrm{g} / \mathrm{kg}(n=49)$ & [103] \\
\hline & & Serum & $0.13 \mu \mathrm{g} / \mathrm{g}(n=467)$ & $0.14 \mu \mathrm{g} / \mathrm{g}(n=936)$ & [104] \\
\hline & Breast & Serum & $90.5 \mathrm{ng} / \mathrm{mL}(n=100)$ & $91.3 \mathrm{ng} / \mathrm{mL}(n=1186)$ & [109] \\
\hline & Liver & Serum & $67.47 \mu \mathrm{g} / \mathrm{L}(n=187)$ & $108.38 \mu \mathrm{g} / \mathrm{L}(n=120)$ & [105] \\
\hline & Colon & Serum & $84.0 \mu \mathrm{g} / \mathrm{L}(n=966)$ & $85.6 \mu \mathrm{g} / \mathrm{L}(n=966)$ & [106] \\
\hline & Pancreas & Serum & $60.0 \mu \mathrm{g} / \mathrm{L}(n=100)$ & $76.0 \mu \mathrm{g} / \mathrm{L}(n=100)$ & [74] \\
\hline & Lung & Serum & $166.00 \mathrm{ng} / \mathrm{g}(n=48)$ & $144.74 \mathrm{ng} / \mathrm{g}(n=39)$ & [100] \\
\hline & Renal & Serum & $161.7 \mu \mathrm{g} / \mathrm{L}(n=401)$ & $288.8 \mu \mathrm{g} / \mathrm{L}(n=774)$ & [102] \\
\hline Phosphorus & Glioblastoma & Tissue & $1.71 \mu \mathrm{g} / \mathrm{cm}^{2}(n=11)$ & $3.01 \mu \mathrm{g} / \mathrm{cm}^{2}(n=11)$ & [75] \\
\hline \multirow[t]{2}{*}{ Iron } & Glioblastoma & Tissue & $0.037 \mu \mathrm{g} / \mathrm{cm}^{2}(n=11)$ & $0.118 \mu \mathrm{g} / \mathrm{cm}^{2}(n=11)$ & [75] \\
\hline & Oral & Serum & $194.6 \mu \mathrm{g} / \mathrm{dL}^{*}$ & $128.6 \mu \mathrm{g} / \mathrm{dL}^{*}$ & [73] \\
\hline \multirow[t]{3}{*}{ Calcium } & Prostate & Tissue & $657 \mathrm{mg} / \mathrm{kg}(n=50)$ & $1431 \mathrm{mg} / \mathrm{kg}(n=49)$ & [103] \\
\hline & Oral & Serum & $14.7 \mathrm{mEq} / \mathrm{L}$ * & $9.4 \mathrm{mEq} / \mathrm{L}^{*}$ & [73] \\
\hline & Ovary & Serum & $9.34 \mathrm{mg} / \mathrm{dL}(n=170)$ & $9.31 \mathrm{mg} / \mathrm{dL}(n=344)$ & [180] \\
\hline
\end{tabular}

${ }^{*}$ No number of people per group reported. ${ }^{\dagger}$ Comparison between tumoral mass and healthy surrounding tissues.

‡ Estimated from article's figures using WebPlotDigitizer v. 4.5 [184].

Table 4. Summary of the daily intake of minerals in the studies retrieved for the present work.

\begin{tabular}{|c|c|c|c|c|}
\hline Mineral & Cancer Entity & $\begin{array}{l}\text { Case Group (Cancer) } \\
\text { Mean Mineral Intake } \\
\text { Number of Patients }\end{array}$ & $\begin{array}{l}\text { Control Group (Healthy) } \\
\text { Mean Mineral Intake } \\
\text { Number of Patients }\end{array}$ & Reference \\
\hline \multirow[t]{2}{*}{ Zinc } & Oral & $12,851 \mu \mathrm{g} /$ day $(n=27)$ & $11,788 \mu \mathrm{g} /$ day $(n=86)$ & {$[71]$} \\
\hline & Bladder & $14.5 \mathrm{mg} /$ day $(n=198)$ & $14.7 \mathrm{mg} /$ day $(n=377)$ & [135] \\
\hline Copper & Bladder & $2.5 \mathrm{mg} /$ day $(n=198)$ & $2.8 \mathrm{mg} /$ day $(n=377)$ & [135] \\
\hline Selenium & Oral & $142.9 \mu \mathrm{g} /$ day $(n=27)$ & $166.7 \mu \mathrm{g} /$ day $(n=86)$ & [71] \\
\hline \multirow[t]{2}{*}{ Phosphorus } & Oral & $1761 \mathrm{mg} /$ day $(n=27)$ & $1431 \mathrm{mg} /$ day $(n=86)$ & {$[71]$} \\
\hline & Bladder & $1898.3 \mathrm{mg} /$ day $(n=198)$ & $1940.4 \mathrm{mg} /$ day $(n=377)$ & [135] \\
\hline \multirow[t]{2}{*}{ Iron } & Oral & $22.4 \mathrm{mg} /$ day $(n=27)$ & $18.9 \mathrm{mg} /$ day $(n=86)$ & {$[71]$} \\
\hline & Bladder & $21.3 \mathrm{mg} /$ day $(n=198)$ & $23.1 \mathrm{mg} /$ day $(n=377)$ & [135] \\
\hline Calcium & Bladder & $1127.2 \mathrm{mg} /$ day $(n=198)$ & $1194.5 \mathrm{mg} /$ day $(n=377)$ & [135] \\
\hline
\end{tabular}

Remarkably, the observation that cancer risk increases with both low and high serum iron levels [161] implies that maintaining physiological levels of micronutrients is critical to avoiding an imbalance of cellular biochemistry that can promote oncogenesis. A balanced diet can ensure the intake of the Goldilocks' quantities of micronutrients, but the depletion of minerals and vitamins in foodstuff makes this increasingly difficult. Regularly checking the mineral levels can help identify whether the physiological range has been met or if the "hidden hunger" has developed increasing the cancer risk.

Given the interdependence of many micronutrients, predicting the role of a single mineral on the oncogenic pathway is cumbersome. For example, serum phosphorus is also linked to calcium and vitamin D and the cellular bioavailability of iron depends on that of vitamin C. Such complexities suggest that minerals may not be suitable cancer biomarkers 
individually, but a panel of said micronutrients, including vitamins, may provide a more complete picture. Because multiple variables must be considered, it is plausible to expect that micronutrient panels would be best analyzed using machine learning approaches, providing personalized indices to assess a potential increased cancer risk.

An imbalanced diet that is often involved in cancer development, is a clear and present danger, especially in industrialized countries. It is not only the high food intake that represents a problem. The vast majority of consumers are unaware of the actual composition of the food or beverages they consume, a situation exacerbated by the fact that food safety authorities do not require manufacturers to declare the actual amounts of micronutrients present in the aliments [185]. The trend in micronutrient depletion reported in the last decades, coupled with the increasing prevalence of the "hidden hunger", suggests that health issues associated with the nutritional deficiency will become more prominent in the near future. According to the World Health Organization, two billion individuals worldwide, including those in wealthy countries, suffer from micronutrient deficiency that is largely clinically undetected [186]. The addition of micronutrients to food (fortification) has been purposely introduced to fight the spread of nutritional deficiencies [187]. However, the effectiveness of this precaution is still debated and does not consider its role on cancer prevention [188-191].

While most knowledge on the medical effect of minerals is associated with high intakes, the impact of mineral deprivation on oncogenesis is still not fully understood. The most recognized medical conditions associated with minerals deficiencies, such as MD, are congenital and include stillbirth, high infant mortality, and impaired development. The role of the mineral deficiency in adulthood and its involvement in oncogenesis is still unclear.

The data gathered here highlight a direct association between high intake of micronutrients (namely copper, iron, and iodine) and cancer risk. The message of this review may point to a potential contradiction: while the average amount of micronutrients in food is decreasing, a higher cancer risk is associated with a higher amount of minerals. The solution to this paradox could be two-sided. On the one side, while most mineral concentrations in food are reduced, some minerals are augmented; this is particularly true for phosphorus and iron, particularly from heme. Mineral depletion, on the other side, may cause cells to adopt a transformed phenotype that abnormally increases the intracellular amount of micronutrients, for example, through the aberrant expression of surface importers.

Assuring a well-balanced diet is a difficult task, especially in a food market dominated by advertisements for "junk food". Rather than relying on labels to report the amounts of selected ingredients (a process hampered by manufacturers' use of incomprehensible chemical names for key health-associated micronutrients), it is more feasible to embrace population-wide nutritional education. If children are educated on a balanced diet beginning in primary school in a few generations, consumers will be the advisors of their nutritional intake without relying too much on labels. Nutrition deficiency will be reduced in this context, as will the biochemical risks associated with micronutrient overload.

\section{Conclusions}

In conclusion, the present review confirms the potential of micronutrients as biomarkers, although the strong interdependence of micronutrient levels, could necessitate looking at a wide range of micronutrients to increase significance of the findings. There was a tendency of a direct link between copper, iron, iodine, phosphorus, and zinc levels and development of different cancer types, with the exception of colon cancer. Selenium serum levels were instead inversely related to cancer risk. However, more data are needed to assess the effectiveness of these biomarkers and if they are suitable only for specific types of cancer. Clustered micronutrient analyses could help the establishment of suitable micronutrient panels with diagnostic value to predict individual cancer risk and to facilitate predictions about the prognosis of particular types of cancer. Furthermore, the individual necessity of supplementation with food supplements, especially micronutrients, should always be critically questioned as long as there is no evident deficiency. 
Author Contributions: Conceptualization, S.V., M.B. and L.M.; investigation, C.L., T.H., O.R. and M.B.; resources, L.M.; data curation, M.B. and L.M.; writing-original draft preparation, L.M.; writing-review and editing, S.V., C.L., T.H., O.R., M.B. and L.M.; visualization, L.M.; supervision, S.V.; project administration, S.V.; funding acquisition, S.V. All authors have read and agreed to the published version of the manuscript.

Funding: This research was funded by PASCOE pharmazeutische Praeparate $\mathrm{GmbH}$, the Ministry of Rural Affairs and Consumer Protection Baden-Wuerttemberg, grant number AZ: 34-9185.90-1, and the Else-Uebelmesser-Stiftung, grant number D3021947; reference: GzV 1.14. We further acknowledge support by the Open Publishing Fund of the University of Tuebingen.

Acknowledgments: We would like to thank Monika Schumacher for the editorial assistance.

Conflicts of Interest: The authors declare no conflict of interest.

\section{Abbreviations}

4E-BP1 eukaryotic translation initiation factor 4E binding protein 1

zinc finger protein A20

AKT

Ak strain transforming

APC

AR

$\mathrm{AscH}^{-}$

adenomatous polyposis coli

ATP7A

average requirement

ATOX1

ascorbate

Braf

CaM

CI

$\mathrm{CNX}$

$\mathrm{Cr}$

ATPase copper transporter 7A

antioxidant-1

rapidly accelerated fibrosarcoma isoform $B$

calmodulin

confidence interval

calnexin

correlation

colorectal carcinoma

calreticulin

CRT

CytC

DMT-1

DNA-pol

EAR

ER

Erp72

ERK

GPx

HCC

HIF-l $\alpha$

HR

cytochrome c

divalent metal transporter 1

DNA polymerase

estimated average requirement

endoplasmic reticulum

endoplasmic reticulum resident protein 72

extracellular signal-regulated kinase

glutathione peroxidase

hepatocellular carcinoma

hypoxia-inducible factor $1 \alpha$

hazard ratio

NF- $\mathrm{kB}$ inhibitor

I $\mathrm{B}$ kinase

IKK

IP3

inositol 1,4,5-trisphosphate

IP3R

K-Ras

LOX

MAPK

MAPKK

MD

MEK

MEMO1

mTORC1

MURR1

$\mathrm{NADH}$

inositol trisphosphate receptor

Kirsten rat sarcoma

lysyl oxidase

mitogen-activated protein kinase

mitogen-activated protein kinase kinase

Menkes disease

MAPK/ERK kinase

mediator of cell motility 1

mammalian target of rapamycin complex 1

mouse U2af1-rs1 region 1

nicotinamide adenine dinucleotide hydride

NF-KB

nuclear factor kappa-light-chain-enhancer of activated B cells 


$\begin{array}{ll}\text { OR } & \text { odds ratio } \\ \text { OS } & \text { overall survival } \\ \text { PI3K } & \text { phosphoinositide 3-kinase } \\ \text { PRI } & \text { population reference intake } \\ \text { ppm } & \text { parts per million } \\ \text { Q } & \text { coenzyme Q } \\ \text { Qt } & \text { quantitative comparison of levels between groups } \\ \text { Raf } & \text { rapidly accelerated fibrosarcoma } \\ \text { Ras } & \text { rat sarcoma virus } \\ \text { RDA } & \text { recommended daily allowance } \\ \text { RNR } & \text { ribonucleotide reductase } \\ \text { ROS } & \text { reactive oxygen species } \\ \text { RR } & \text { relative risk } \\ \text { Sec } & \text { selenocysteine } \\ \text { SECIS } & \text { Sec insertion sequence } \\ \text { Sep15 } & \text { selenoprotein of 15-kDa } \\ \text { SERCA } & \text { sarco/endoplasmic reticulum calcium ATPase } \\ \text { SOD } & \text { superoxide dismutase } \\ \text { SPARC } & \text { secreted protein acidic and rich in cysteine } \\ \text { TR1 } & \text { thioredoxin reductase 1 } \\ \text { UL } & \text { tolerable upper intake level } \\ \text { ULK } & \text { Unc-51-like autophagy activating kinase } \\ \text { Wnt } & \text { wingless /int-1 } \\ \text { XIAP } & \text { X-linked inhibitor of apoptosis }\end{array}$

\section{References}

1. Swinburn, B.; Sacks, G.; Ravussin, E. Increased Food Energy Supply Is More than Sufficient to Explain the US Epidemic of Obesity. Am. J. Clin. Nutr. 2009, 90, 1453-1456. [CrossRef] [PubMed]

2. Swinburn, B.A.; Sacks, G.; Hall, K.D.; McPherson, K.; Finegood, D.T.; Moodie, M.L.; Gortmaker, S.L. The Global Obesity Pandemic: Shaped by Global Drivers and Local Environments. Lancet Lond. Engl. 2011, 378, 804-814. [CrossRef]

3. Thomas, D. A Study on the Mineral Depletion of the Foods Available to Us as a Nation over the Period 1940 to 1991. Nutr. Health 2003, 17, 85-115. [CrossRef]

4. Thomas, D. The Mineral Depletion of Foods Available to Us as a Nation (1940-2002) —A Review of the 6th Edition of McCance and Widdowson. Nutr. Health 2007, 19, 21-55. [CrossRef] [PubMed]

5. Mayer, A.-M.B.; Trenchard, L.; Rayns, F. Historical Changes in the Mineral Content of Fruit and Vegetables in the UK from 1940 to 2019: A Concern for Human Nutrition and Agriculture. Int. J. Food Sci. Nutr. 2021, 1-12. [CrossRef]

6. Muthayya, S.; Rah, J.H.; Sugimoto, J.D.; Roos, F.F.; Kraemer, K.; Black, R.E. The Global Hidden Hunger Indices and Maps: An Advocacy Tool for Action. PLoS ONE 2013, 8, e67860. [CrossRef] [PubMed]

7. Biesalski, H.K.; Tinz, J. Multivitamin/Mineral Supplements: Rationale and Safety-A Systematic Review. Nutrition 2017, 33, 76-82. [CrossRef] [PubMed]

8. Shenkin, A. Micronutrients in Health and Disease. Postgrad. Med. J. 2006, 82, 559-567. [CrossRef]

9. Calder, P.C. Feeding the Immune System. Proc. Nutr. Soc. 2013, 72, 299-309. [CrossRef] [PubMed]

10. Shakoor, H.; Feehan, J.; Al Dhaheri, A.S.; Ali, H.I.; Platat, C.; Ismail, L.C.; Apostolopoulos, V.; Stojanovska, L. Immune-Boosting Role of Vitamins D, C, E, Zinc, Selenium and Omega-3 Fatty Acids: Could They Help against COVID-19? Maturitas 2021, 143, 1-9. [CrossRef] [PubMed]

11. Ribatti, D. The Concept of Immune Surveillance against Tumors. The First Theories. Oncotarget 2017, 8, 7175-7180. [CrossRef] [PubMed]

12. European Food Safety Authority (EFSA). Summary of Tolerable Upper Intake Levels—Version 4. Overview on Tolerable Upper Intake Levels as Derived by the Scientific Committee on Food (SCF) and the EFSA Panel on Dietetic Products, Nutrition and Allergies (NDA). 2018, p. 2. Available online: https://www.efsa.europa.eu/sites/default/files/assets/UL_Summary_tables.pdf (accessed on 21 February 2022).

13. EFSA Panel on Dietetic Products, Nutrition and Allergies (NDA). Scientific Opinion on Dietary Reference Values for Iron. EFSA J. 2014, 13, 4254. [CrossRef]

14. European Food Safety Authority (EFSA). Summary of Dietary Reference Values-Version 4. Overview on Dietary Reference Values for the EU Population as Derived by the EFSA Panel on Dietetic Products, Nutrition and Allergies (NDA). 2017, p. 5. Available online: https://www.efsa.europa.eu/sites/default/files/assets/DRV_Summary_tables_jan_17.pdf (accessed on 21 February 2022).

15. EFSA Panel on Dietetic Products, Nutrition and Allergies (NDA). Scientific Opinion on Dietary Reference Values for Zinc. EFSA J. 2014, 12, 3844. [CrossRef] 
16. Yokokawa, H.; Fukuda, H.; Saita, M.; Miyagami, T.; Takahashi, Y.; Hisaoka, T.; Naito, T. Serum zinc concentrations and characteristics of zinc deficiency/marginal deficiency among Japanese subjects. J. Gen. Fam. Med. 2020, 21, 248-255. [CrossRef] [PubMed]

17. EFSA Panel on Dietetic Products, Nutrition and Allergies (NDA). Scientific Opinion on Dietary Reference Values for Selenium. EFSA J. 2014, 12, 3846. [CrossRef]

18. EFSA Panel on Dietetic Products, Nutrition and Allergies (NDA). Scientific Opinion on Dietary Reference Values for Phosphorus. EFSA J. 2014, 13, 4185. [CrossRef]

19. EFSA Panel on Dietetic Products, Nutrition and Allergies (NDA). Scientific Opinion on Dietary Reference Values for Calcium. EFSA J. 2015, 13, 4101. [CrossRef]

20. EFSA Panel on Dietetic Products, Nutrition and Allergies (NDA). Scientific Opinion on Dietary Reference Values for Copper. EFSA J. 2015, 13, 4253. [CrossRef]

21. EFSA Panel on Dietetic Products, Nutrition and Allergies (NDA). Scientific Opinion on Dietary Reference Values for Iodine. EFSA J. 2014, 12, 3660. [CrossRef]

22. Blockhuys, S.; Wittung-Stafshede, P. Roles of Copper-Binding Proteins in Breast Cancer. Int. J. Mol. Sci. 2017, 18, 871. [CrossRef] [PubMed]

23. Li, Y. Copper Homeostasis: Emerging Target for Cancer Treatment. IUBMB Life 2020, 72, 1900-1908. [CrossRef] [PubMed]

24. Harrison, M.D.; Dameron, C.T. Molecular Mechanisms of Copper Metabolism and the Role of the Menkes Disease Protein. J. Biochem. Mol. Toxicol. 1999, 13, 93-106. [CrossRef]

25. Michalczyk, K.; Cymbaluk-Płoska, A. The Role of Zinc and Copper in Gynecological Malignancies. Nutrients 2020, 12, 3732 [CrossRef] [PubMed]

26. Guo, J.; Cheng, J.; Zheng, N.; Zhang, X.; Dai, X.; Zhang, L.; Hu, C.; Wu, X.; Jiang, Q.; Wu, D.; et al. Copper Promotes Tumorigenesis by Activating the PDK1-AKT Oncogenic Pathway in a Copper Transporter 1 Dependent Manner. Adv. Sci. 2021, 8, e2004303. [CrossRef] [PubMed]

27. Gupte, A.; Mumper, R.J. Elevated Copper and Oxidative Stress in Cancer Cells as a Target for Cancer Treatment. Cancer Treat. Rev. 2009, 35, 32-46. [CrossRef] [PubMed]

28. da Silva, D.A.; de Luca, A.; Squitti, R.; Rongioletti, M.; Rossi, L.; Machado, C.M.L.; Cerchiaro, G. Copper in tumors and the use of copper-based compounds in cancer treatment. J. Inorg. Biochem. 2022, 226, 111634. [CrossRef]

29. Stepien, M.; Jenab, M.; Freisling, H.; Becker, N.-P.; Czuban, M.; Tjønneland, A.; Olsen, A.; Overvad, K.; Boutron-Ruault, M.-C.; Mancini, F.R.; et al. Pre-Diagnostic Copper and Zinc Biomarkers and Colorectal Cancer Risk in the European Prospective Investigation into Cancer and Nutrition Cohort. Carcinogenesis 2017, 38, 699-707. [CrossRef]

30. Gupta, S.K.; Singh, S.P.; Shukla, V.K. Copper, Zinc, and Cu/Zn Ratio in Carcinoma of the Gallbladder. J. Surg. Oncol. 2005, 91, 204-208. [CrossRef]

31. Dìez, M.; Cerdàn, F.J.; Arroyo, M.; Balibrea, J.L. Use of the Copper/Zinc Ratio in the Diagnosis of Lung Cancer. Cancer 1989, 63, 726-730. [CrossRef]

32. Feng, Y.; Zeng, J.-W.; Ma, Q.; Zhang, S.; Tang, J.; Feng, J.-F. Serum Copper and Zinc Levels in Breast Cancer: A Meta-Analysis. J. Trace Elem. Med. Biol. Organ. Soc. Miner. Trace Elem. GMS 2020, 62, 126629. [CrossRef]

33. Atakul, T.; Altinkaya, S.O.; Abas, B.I.; Yenisey, C. Serum Copper and Zinc Levels in Patients with Endometrial Cancer. Biol. Trace Elem. Res. 2020, 195, 46-54. [CrossRef]

34. Naidu, M.S.K.; Suryakar, A.N.; Swami, S.C.; Katkam, R.V.; Kumbar, K.M. Oxidative Stress and Antioxidant Status in Cervical Cancer Patients. Indian J. Clin. Biochem. 2007, 22, 140-144. [CrossRef] [PubMed]

35. Burstein, E.; Ganesh, L.; Dick, R.D.; van De Sluis, B.; Wilkinson, J.C.; Klomp, L.W.J.; Wijmenga, C.; Brewer, G.J.; Nabel, G.J.; Duckett, C.S. A Novel Role for XIAP in Copper Homeostasis through Regulation of MURR1. EMBO J. 2004, 23, $244-254$. [CrossRef]

36. van De Sluis, B.; Rothuizen, J.; Pearson, P.L.; van Oost, B.A.; Wijmenga, C. Identification of a New Copper Metabolism Gene by Positional Cloning in a Purebred Dog Population. Hum. Mol. Genet. 2002, 11, 165-173. [CrossRef] [PubMed]

37. Blockhuys, S.; Celauro, E.; Hildesjö, C.; Feizi, A.; Stål, O.; Fierro-González, J.C.; Wittung-Stafshede, P. Defining the Human Copper Proteome and Analysis of Its Expression Variation in Cancers. Met. Integr. Biometal Sci. 2017, 9, 112-123. [CrossRef] [PubMed]

38. Rigiracciolo, D.C.; Scarpelli, A.; Lappano, R.; Pisano, A.; Santolla, M.F.; De Marco, P.; Cirillo, F.; Cappello, A.R.; Dolce, V.; Belfiore, A.; et al. Copper Activates HIF-1 $\alpha$ /GPER/VEGF Signalling in Cancer Cells. Oncotarget 2015, 6, 34158-34177. [CrossRef]

39. Xiao, Q.; Ge, G. Lysyl Oxidase, Extracellular Matrix Remodeling and Cancer Metastasis. Cancer Microenviron. Off. J. Int. Cancer Microenviron. Soc. 2012, 5, 261-273. [CrossRef]

40. Levental, K.R.; Yu, H.; Kass, L.; Lakins, J.N.; Egeblad, M.; Erler, J.T.; Fong, S.F.T.; Csiszar, K.; Giaccia, A.; Weninger, W.; et al. Matrix Crosslinking Forces Tumor Progression by Enhancing Integrin Signaling. Cell 2009, 139, 891-906. [CrossRef]

41. Arnold, S.A.; Brekken, R.A. SPARC: A Matricellular Regulator of Tumorigenesis. J. Cell Commun. Signal. 2009, 3, $255-273$. [CrossRef] [PubMed]

42. Sorokin, A.V.; Chen, J. MEMO1, a New IRS1-Interacting Protein, Induces Epithelial-Mesenchymal Transition in Mammary Epithelial Cells. Oncogene 2013, 32, 3130-3138. [CrossRef] [PubMed]

43. Iturbide, A.; de Herreros, A.G.; Peiró, S. A New Role for LOX and LOXL2 Proteins in Transcription Regulation. FEBS J. 2015, 282, 1768-1773. [CrossRef] [PubMed] 
44. Brady, D.C.; Crowe, M.S.; Turski, M.L.; Hobbs, G.A.; Yao, X.; Chaikuad, A.; Knapp, S.; Xiao, K.; Campbell, S.L.; Thiele, D.J.; et al. Copper Is Required for Oncogenic BRAF Signalling and Tumorigenesis. Nature 2014, 509, 492-496. [CrossRef] [PubMed]

45. Lemieux, E.; Bergeron, S.; Durand, V.; Asselin, C.; Saucier, C.; Rivard, N. Constitutively Active MEK1 Is Sufficient to Induce Epithelial-to-Mesenchymal Transition in Intestinal Epithelial Cells and to Promote Tumor Invasion and Metastasis. Int. J. Cancer 2009, 125, 1575-1586. [CrossRef]

46. Turski, M.L.; Brady, D.C.; Kim, H.J.; Kim, B.-E.; Nose, Y.; Counter, C.M.; Winge, D.R.; Thiele, D.J. A Novel Role for Copper in Ras/Mitogen-Activated Protein Kinase Signaling. Mol. Cell. Biol. 2012, 32, 1284-1295. [CrossRef]

47. Kunz, M.; Vera, J. Modelling of Protein Kinase Signaling Pathways in Melanoma and Other Cancers. Cancers 2019, 11, 465. [CrossRef]

48. Klein, E.A.; Assoian, R.K. Transcriptional Regulation of the Cyclin D1 Gene at a Glance. J. Cell Sci. 2008, 121, 3853-3857. [CrossRef] [PubMed]

49. Itoh, S.; Ozumi, K.; Kim, H.W.; Nakagawa, O.; McKinney, R.D.; Folz, R.J.; Zelko, I.N.; Ushio-Fukai, M.; Fukai, T. Novel Mechanism for Regulation of Extracellular SOD Transcription and Activity by Copper: Role of Antioxidant-1. Free Radic. Biol. Med. 2009, 46, 95-104. [CrossRef]

50. Ozumi, K.; Sudhahar, V.; Kim, H.W.; Chen, G.-F.; Kohno, T.; Finney, L.; Vogt, S.; McKinney, R.D.; Ushio-Fukai, M.; Fukai, T. Role of Copper Transport Protein Antioxidant 1 in Angiotensin II-Induced Hypertension: A Key Regulator of Extracellular Superoxide Dismutase. Hypertension 2012, 60, 476-486. [CrossRef]

51. Wang, X.; Lee, J.; Xie, C. Autophagy Regulation on Cancer Stem Cell Maintenance, Metastasis, and Therapy Resistance. Cancers 2022, 14, 381. [CrossRef]

52. Redza-Dutordoir, M.; Averill-Bates, D.A. Interactions between Reactive Oxygen Species and Autophagy: Special Issue: Death Mechanisms in Cellular Homeostasis. Biochim. Biophys. Acta Mol. Cell Res. 2021, 1868, 119041. [CrossRef]

53. Tsang, T.; Posimo, J.M.; Gudiel, A.A.; Cicchini, M.; Feldser, D.M.; Brady, D.C. Copper Is an Essential Regulator of the Autophagic Kinases ULK1/2 to Drive Lung Adenocarcinoma. Nat. Cell Biol. 2020, 22, 412-424. [CrossRef] [PubMed]

54. Zischka, H.; Kroemer, G. Copper-A Novel Stimulator of Autophagy. Cell Stress 2020, 4, 92-94. [CrossRef] [PubMed]

55. Evanics, F.; Maurmann, L.; Yang, W.W.; Bose, R.N. Nuclear Magnetic Resonance Structures of the Zinc Finger Domain of Human DNA Polymerase-Alpha. Biochim. Biophys. Acta 2003, 1651, 163-171. [CrossRef]

56. Baranovskiy, A.G.; Zhang, Y.; Suwa, Y.; Babayeva, N.D.; Gu, J.; Pavlov, Y.I.; Tahirov, T.H. Crystal Structure of the Human Primase J. Biol. Chem. 2015, 290, 5635-5646. [CrossRef] [PubMed]

57. Skrajnowska, D.; Bobrowska-Korczak, B. Role of Zinc in Immune System and Anti-Cancer Defense Mechanisms. Nutrients 2019, 11, 2273. [CrossRef]

58. Jarosz, M.; Olbert, M.; Wyszogrodzka, G.; Młyniec, K.; Librowski, T. Antioxidant and Anti-Inflammatory Effects of Zinc. Zinc-Dependent NF-KB Signaling. Inflammopharmacology 2017, 25, 11-24. [CrossRef] [PubMed]

59. Sen, R.; Baltimore, D. Multiple Nuclear Factors Interact with the Immunoglobulin Enhancer Sequences. Cell 1986, 46, 705-716. [CrossRef]

60. Zhang, Q.; Lenardo, M.J.; Baltimore, D. 30 Years of NF-KB: A Blossoming of Relevance to Human Pathobiology. Cell 2017, 168, 37-57. [CrossRef] [PubMed]

61. Yi, P.S.; Shu, Y.; Bi, W.X.; Zheng, X.B.; Feng, W.J.; He, L.Y.; Li, J.S. Emerging Role of Zinc Finger Protein A20 as a Suppressor of Hepatocellular Carcinoma. J. Cell. Physiol. 2019, 234, 21479-21484. [CrossRef]

62. Prasad, A.S. Zinc: Mechanisms of Host Defense. J. Nutr. 2007, 137, 1345-1349. [CrossRef] [PubMed]

63. Zelko, I.N.; Mariani, T.J.; Folz, R.J. Superoxide Dismutase Multigene Family: A Comparison of the CuZn-SOD (SOD1), Mn-SOD (SOD2), and EC-SOD (SOD3) Gene Structures, Evolution, and Expression. Free Radic. Biol. Med. 2002, 33, 337-349. [CrossRef]

64. Fukai, T.; Ushio-Fukai, M. Superoxide Dismutases: Role in Redox Signaling, Vascular Function, and Diseases. Antioxid. Redox Signal. 2011, 15, 1583-1606. [CrossRef]

65. Laskey, J.; Webb, I.; Schulman, H.M.; Ponka, P. Evidence That Transferrin Supports Cell Proliferation by Supplying Iron for DNA Synthesis. Exp. Cell Res. 1988, 176, 87-95. [CrossRef]

66. Radi, R. Oxygen Radicals, Nitric Oxide, and Peroxynitrite: Redox Pathways in Molecular Medicine. Proc. Natl. Acad. Sci. USA 2018, 115, 5839-5848. [CrossRef]

67. Lewandowski, Ł.; Kepinska, M.; Milnerowicz, H. The Copper-Zinc Superoxide Dismutase Activity in Selected Diseases. Eur. J. Clin. Investig. 2019, 49, e13036. [CrossRef] [PubMed]

68. Koren, O.; Tako, E. Chronic Dietary Zinc Deficiency Alters Gut Microbiota Composition and Function. Proceedings 2020, $61,16$.

69. Collins, D.; Hogan, A.M.; Winter, D.C. Microbial and Viral Pathogens in Colorectal Cancer. Lancet Oncol. 2011, 12, 504-512. [CrossRef]

70. Rusch, P.; Hirner, A.V.; Schmitz, O.; Kimmig, R.; Hoffmann, O.; Diel, M. Zinc Distribution within Breast Cancer Tissue of Different Intrinsic Subtypes. Arch. Gynecol. Obstet. 2021, 303, 195-205. [CrossRef] [PubMed]

71. Secchi, D.G.; Aballay, L.R.; Galíndez, M.F.; Piccini, D.; Lanfranchi, H.; Brunotto, M. Red Meat, Micronutrients and Oral Squamous Cell Carcinoma of Argetine Adult Patients. Nutr. Hosp. 2015, 32, 1214-1221.

72. Fang, A.-P.; Chen, P.-Y.; Wang, X.-Y.; Liu, Z.-Y.; Zhang, D.-M.; Luo, Y.; Liao, G.-C.; Long, J.-A.; Zhong, R.-H.; Zhou, Z.-G.; et al Serum Copper and Zinc Levels at Diagnosis and Hepatocellular Carcinoma Survival in the Guangdong Liver Cancer Cohort. Int. J. Cancer 2019, 144, 2823-2832. [CrossRef] [PubMed] 
73. Elango, S.; Samuel, S.; Khashim, Z.; Subbiah, U. Selenium Influences Trace Elements Homeostasis, Cancer Biomarkers in Squamous Cell Carcinoma Patients Administered with Cancerocidal Radiotherapy. Asian Pac. J. Cancer Prev. 2018, 19, 1785-1792. [CrossRef] [PubMed]

74. Lener, M.R.; Scott, R.J.; Wiechowska-Kozłowska, A.; Serrano-Fernández, P.; Baszuk, P.; Jaworska-Bieniek, K.; Sukiennicki, G.; Marciniak, W.; Muszyńska, M.; Kładny, J.; et al. Serum Concentrations of Selenium and Copper in Patients Diagnosed with Pancreatic Cancer. Cancer Res. Treat. 2016, 48, 1056-1064. [CrossRef] [PubMed]

75. Wandzilak, A.; Czyzycki, M.; Radwanska, E.; Adamek, D.; Geraki, K.; Lankosz, M. X-ray Fluorescence Study of the Concentration of Selected Trace and Minor Elements in Human Brain Tumours. Spectrochim. Acta Part. B At. Spectrosc. 2015, $114,52-57$. [CrossRef]

76. Dehnhardt, M.; Zoriy, M.V.; Khan, Z.; Reifenberger, G.; Ekström, T.J.; Sabine Becker, J.; Zilles, K.; Bauer, A. Element Distribution Is Altered in a Zone Surrounding Human Glioblastoma Multiforme. J. Trace Elem. Med. Biol. Organ. Soc. Miner. Trace Elem. GMS 2008, 22, 17-23. [CrossRef] [PubMed]

77. Turecký, L.; Kalina, P.; Uhlíková, E.; Námerová, S.; Krizko, J. Serum Ceruloplasmin and Copper Levels in Patients with Primary Brain Tumors. Klin. Wochenschr. 1984, 62, 187-189. [CrossRef]

78. Tamai, Y.; Iwasa, M.; Eguchi, A.; Shigefuku, R.; Sugimoto, K.; Hasegawa, H.; Takei, Y. Serum Copper, Zinc and Metallothionein Serve as Potential Biomarkers for Hepatocellular Carcinoma. PLoS ONE 2020, 15, e0237370. [CrossRef]

79. Schwarz, K.; Foltz, C.M. Factor 3 Activity of Selenium Compounds. J. Biol. Chem. 1958, 233, 245-251. [CrossRef]

80. Razaghi, A.; Poorebrahim, M.; Sarhan, D.; Björnstedt, M. Selenium Stimulates the Antitumour Immunity: Insights to Future Research. Eur. J. Cancer 2021, 155, 256-267. [CrossRef] [PubMed]

81. Selenius, M.; Rundlöf, A.-K.; Olm, E.; Fernandes, A.P.; Björnstedt, M. Selenium and the Selenoprotein Thioredoxin Reductase in the Prevention, Treatment and Diagnostics of Cancer. Antioxid. Redox Signal. 2010, 12, 867-880. [CrossRef] [PubMed]

82. Jones, G.D.; Droz, B.; Greve, P.; Gottschalk, P.; Poffet, D.; McGrath, S.P.; Seneviratne, S.I.; Smith, P.; Winkel, L.H.E. Selenium Deficiency Risk Predicted to Increase under Future Climate Change. Proc. Natl. Acad. Sci. USA 2017, 114, 2848-2853. [CrossRef]

83. Vinceti, M.; Filippini, T.; Wise, L.A. Environmental Selenium and Human Health: An Update. Curr. Environ. Health Rep. 2018, 5, 464-485. [CrossRef]

84. Rayman, M.P. Food-Chain Selenium and Human Health: Emphasis on Intake. Br. J. Nutr. 2008, 100, 254-268. [CrossRef] [PubMed]

85. Radomska, D.; Czarnomysy, R.; Radomski, D.; Bielawska, A.; Bielawski, K. Selenium as a Bioactive Micronutrient in the Human Diet and Its Cancer Chemopreventive Activity. Nutrients 2021, 13, 1649. [CrossRef] [PubMed]

86. Prabhu, K.S.; Lei, X.G. Selenium. Adv. Nutr. 2016, 7, 415-417. [CrossRef] [PubMed]

87. Kryukov, G.V.; Castellano, S.; Novoselov, S.V.; Lobanov, A.V.; Zehtab, O.; Guigó, R.; Gladyshev, V.N. Characterization of Mammalian Selenoproteomes. Science 2003, 300, 1439-1443. [CrossRef] [PubMed]

88. Conrad, M.; Schweizer, U. Unveiling the Molecular Mechanisms behind Selenium-Related Diseases through Knockout Mouse Studies. Antioxid. Redox Signal. 2010, 12, 851-865. [CrossRef] [PubMed]

89. Hatfield, D.L.; Tsuji, P.A.; Carlson, B.A.; Gladyshev, V.N. Selenium and Selenocysteine: Roles in Cancer, Health, and Development. Trends Biochem. Sci. 2014, 39, 112-120. [CrossRef]

90. Lu, J.; Holmgren, A. The Thioredoxin Antioxidant System. Free Radic. Biol. Med. 2014, 66, 75-87. [CrossRef] [PubMed]

91. Urig, S.; Becker, K. On the Potential of Thioredoxin Reductase Inhibitors for Cancer Therapy. Semin. Cancer Biol. 2006, 16, 452-465. [CrossRef] [PubMed]

92. Liu, Y.; Li, Y.; Yu, S.; Zhao, G. Recent Advances in the Development of Thioredoxin Reductase Inhibitors as Anticancer Agents Curr. Drug Targets 2012, 13, 1432-1444. [CrossRef] [PubMed]

93. Kasaikina, M.V.; Fomenko, D.E.; Labunskyy, V.M.; Lachke, S.A.; Qiu, W.; Moncaster, J.A.; Zhang, J.; Wojnarowicz, M.W.J.; Natarajan, S.K.; Malinouski, M.; et al. Roles of the 15-KDa Selenoprotein (Sep15) in Redox Homeostasis and Cataract Development Revealed by the Analysis of Sep 15 Knockout Mice. J. Biol. Chem. 2011, 286, 33203-33212. [CrossRef] [PubMed]

94. Jablonska, E.; Gromadzinska, J.; Sobala, W.; Reszka, E.; Wasowicz, W. Lung Cancer Risk Associated with Selenium Status Is Modified in Smoking Individuals by Sep15 Polymorphism. Eur. J. Nutr. 2008, 47, 47-54. [CrossRef] [PubMed]

95. Irons, R.; Tsuji, P.A.; Carlson, B.A.; Ouyang, P.; Yoo, M.-H.; Xu, X.-M.; Hatfield, D.L.; Gladyshev, V.N.; Davis, C.D. Deficiency in the 15-KDa Selenoprotein Inhibits Tumorigenicity and Metastasis of Colon Cancer Cells. Cancer Prev. Res. 2010, 3, 630-639. [CrossRef] [PubMed]

96. Kipp, A.P.; Müller, M.F.; Göken, E.M.; Deubel, S.; Brigelius-Flohé, R. The Selenoproteins GPx2, TrxR2 and TrxR3 Are Regulated by Wnt Signalling in the Intestinal Epithelium. Biochim. Biophys. Acta 2012, 1820, 1588-1596. [CrossRef]

97. Kipp, A.P. Selenium in Colorectal and Differentiated Thyroid Cancer. Horm. Athens Greece 2020, 19, 41-46. [CrossRef] [PubMed]

98. Coates, R.J.; Weiss, N.S.; Daling, J.R.; Morris, J.S.; Labbe, R.F. Serum Levels of Selenium and Retinol and the Subsequent Risk of Cancer. Am. J. Epidemiol. 1988, 128, 515-523. [CrossRef] [PubMed]

99. Brodin, O.; Hackler, J.; Misra, S.; Wendt, S.; Sun, Q.; Laaf, E.; Stoppe, C.; Björnstedt, M.; Schomburg, L. Selenoprotein P as Biomarker of Selenium Status in Clinical Trials with Therapeutic Dosages of Selenite. Nutrients 2020, 12, 1067. [CrossRef]

100. Callejón-Leblic, B.; Rodríguez-Moro, G.; Arias-Borrego, A.; Pereira-Vega, A.; Gómez-Ariza, J.L.; García-Barrera, T. Absolute Quantification of Selenoproteins and Selenometabolites in Lung Cancer Human Serum by Column Switching Coupled to Triple Quadrupole Inductively Coupled Plasma Mass Spectrometry. J. Chromatogr. A 2020, 1619, 460919. [CrossRef] 
101. Pietrzak, S.; Wójcik, J.; Scott, R.J.; Kashyap, A.; Grodzki, T.; Baszuk, P.; Bielewicz, M.; Marciniak, W.; Wójcik, N.; Dębniak, T.; et al. Influence of the Selenium Level on Overall Survival in Lung Cancer. J. Trace Elem. Med. Biol. Organ. Soc. Miner. Trace Elem. GMS 2019, 56, 46-51. [CrossRef] [PubMed]

102. Hsueh, Y.-M.; Lin, Y.-C.; Huang, Y.-L.; Shiue, H.-S.; Pu, Y.-S.; Huang, C.-Y.; Chung, C.-J. Effect of Plasma Selenium, Red Blood Cell Cadmium, Total Urinary Arsenic Levels, and EGFR on Renal Cell Carcinoma. Sci. Total Environ. 2021, 750, 141547. [CrossRef]

103. Çelen, İ.; Müezzinoğlu, T.; Ataman, O.Y.; Bakırdere, S.; Korkmaz, M.; Neşe, N.; Şenol, F.; Lekili, M. Selenium, Nickel, and Calcium Levels in Cancerous and Non-Cancerous Prostate Tissue Samples and Their Relation with Some Parameters. Environ. Sci. Pollut. Res. Int. 2015, 22, 13070-13076. [CrossRef] [PubMed]

104. Gill, J.K.; Franke, A.A.; Steven Morris, J.; Cooney, R.V.; Wilkens, L.R.; Le Marchand, L.; Goodman, M.T.; Henderson, B.E.; Kolonel, L.N. Association of Selenium, Tocopherols, Carotenoids, Retinol, and 15-Isoprostane F(2t) in Serum or Urine with Prostate Cancer Risk: The Multiethnic Cohort. Cancer Causes Control 2009, 20, 1161-1171. [CrossRef] [PubMed]

105. Kim, I.-W.; Bae, S.-M.; Kim, Y.-W.; Liu, H.-B.; Bae, S.H.; Choi, J.Y.; Yoon, S.K.; Chaturvedi, P.K.; Battogtokh, G.; Ahn, W.S. Serum Selenium Levels in Korean Hepatoma Patients. Biol. Trace Elem. Res. 2012, 148, 25-31. [CrossRef] [PubMed]

106. Hughes, D.J.; Fedirko, V.; Jenab, M.; Schomburg, L.; Méplan, C.; Freisling, H.; Bueno-de-Mesquita, H.B.; Hybsier, S.; Becker, N.-P.; Czuban, M.; et al. Selenium Status Is Associated with Colorectal Cancer Risk in the European Prospective Investigation of Cancer and Nutrition Cohort. Int. J. Cancer 2015, 136, 1149-1161. [CrossRef]

107. Xie, B.; Lin, J.; Sui, K.; Huang, Z.; Chen, Z.; Hang, W. Differential Diagnosis of Multielements in Cancerous and Non-Cancerous Esophageal Tissues. Talanta 2019, 196, 585-591. [CrossRef] [PubMed]

108. Gül-Klein, S.; Haxhiraj, D.; Seelig, J.; Kästner, A.; Hackler, J.; Sun, Q.; Heller, R.A.; Lachmann, N.; Pratschke, J.; Schmelzle, M.; et al Serum Selenium Status as a Diagnostic Marker for the Prognosis of Liver Transplantation. Nutrients 2021, 13, 619. [CrossRef] [PubMed]

109. Sandsveden, M.; Nilsson, E.; Borgquist, S.; Rosendahl, A.H.; Manjer, J. Prediagnostic Serum Selenium Levels in Relation to Breast Cancer Survival and Tumor Characteristics. Int. J. Cancer 2020, 147, 2424-2436. [CrossRef] [PubMed]

110. Lubinski, J.; Marciniak, W.; Muszynska, M.; Huzarski, T.; Gronwald, J.; Cybulski, C.; Jakubowska, A.; Debniak, T.; Falco, M.; Kladny, J.; et al. Serum Selenium Levels Predict Survival after Breast Cancer. Breast Cancer Res. Treat. 2018, 167, 591-598. [CrossRef] [PubMed]

111. Berner, Y.N.; Shike, M. Consequences of Phosphate Imbalance. Annu. Rev. Nutr. 1988, 8, 121-148. [CrossRef] [PubMed]

112. Calvo, M.S.; Tucker, K.L. Is Phosphorus Intake That Exceeds Dietary Requirements a Risk Factor in Bone Health? Ann. N. Y. Acad. Sci. 2013, 1301, 29-35. [CrossRef] [PubMed]

113. Kalantar-Zadeh, K.; Gutekunst, L.; Mehrotra, R.; Kovesdy, C.P.; Bross, R.; Shinaberger, C.S.; Noori, N.; Hirschberg, R.; Benner, D.; Nissenson, A.R.; et al. Understanding Sources of Dietary Phosphorus in the Treatment of Patients with Chronic Kidney Disease. Clin. J. Am. Soc. Nephrol. 2010, 5, 519-530. [CrossRef]

114. Takeda, E.; Yamamoto, H.; Yamanaka-Okumura, H.; Taketani, Y. Increasing Dietary Phosphorus Intake from Food Additives: Potential for Negative Impact on Bone Health. Adv. Nutr. 2014, 5, 92-97. [CrossRef] [PubMed]

115. Sheard, P.R.; Nute, G.R.; Richardson, R.I.; Perry, A.; Taylor, A.A. Injection of Water and Polyphosphate into Pork to Improve Juiciness and Tenderness after Cooking. Meat Sci. 1999, 51, 371-376. [CrossRef]

116. Shimada, M.; Shutto-Uchita, Y.; Yamabe, H. Lack of Awareness of Dietary Sources of Phosphorus Is a Clinical Concern. Vivo Athens Greece 2019, 33, 11-16. [CrossRef] [PubMed]

117. Anderson, J.J.B. Potential Health Concerns of Dietary Phosphorus: Cancer, Obesity, and Hypertension. Ann. N. Y. Acad. Sci. 2013, 1301, 1-8. [CrossRef] [PubMed]

118. Calvo, M.S. Dietary Phosphorus, Calcium Metabolism and Bone. J. Nutr. 1993, 123, 1627-1633. [CrossRef] [PubMed]

119. Serna, J.; Bergwitz, C. Importance of Dietary Phosphorus for Bone Metabolism and Healthy Aging. Nutrients 2020, $12,3001$. [CrossRef] [PubMed]

120. Venturelli, S.; Leischner, C.; Helling, T.; Burkard, M.; Marongiu, L. Vitamins as Possible Cancer Biomarkers: Significance and Limitations. Nutrients 2021, 13, 3914. [CrossRef] [PubMed]

121. Giovannucci, E. Dietary Influences of 1,25(OH)2 Vitamin D in Relation to Prostate Cancer: A Hypothesis. Cancer Causes Control 1998, 9, 567-582. [CrossRef]

122. Brown, R.B. Vitamin D, Cancer, and Dysregulated Phosphate Metabolism. Endocrine 2019, 65, 238-243. [CrossRef]

123. Kapur, S. A Medical Hypothesis: Phosphorus Balance and Prostate Cancer. Cancer Investig. 2000, 18, 664-669. [CrossRef] [PubMed]

124. Waterhouse, M.; Hope, B.; Krause, L.; Morrison, M.; Protani, M.M.; Zakrzewski, M.; Neale, R.E. Vitamin D and the Gut Microbiome: A Systematic Review of In Vivo Studies. Eur. J. Nutr. 2019, 58, 2895-2910. [CrossRef] [PubMed]

125. Papaloucas, C.D.; Papaloucas, M.D.; Kouloulias, V.; Neanidis, K.; Pistevou-Gompaki, K.; Kouvaris, J.; Zygogianni, A.; Mystakidou, K.; Papaloucas, A.C. Measurement of Blood Phosphorus: A Quick and Inexpensive Method for Detection of the Existence of Cancer in the Body. Too Good to Be True, or Forgotten Knowledge of the Past? Med. Hypotheses 2014, 82, 24-25. [CrossRef] [PubMed]

126. Elser, J.J.; Kyle, M.M.; Smith, M.S.; Nagy, J.D. Biological Stoichiometry in Human Cancer. PLoS ONE 2007, 2, e1028. [CrossRef] 
127. Jin, H.; Xu, C.-X.; Lim, H.-T.; Park, S.-J.; Shin, J.-Y.; Chung, Y.-S.; Park, S.-C.; Chang, S.-H.; Youn, H.-J.; Lee, K.-H.; et al. High Dietary Inorganic Phosphate Increases Lung Tumorigenesis and Alters Akt Signaling. Am. J. Respir. Crit. Care Med. 2009, 179, 59-68. [CrossRef]

128. Chang, S.-H.; Yu, K.N.; Lee, Y.-S.; An, G.-H.; Beck, G.R.J.; Colburn, N.H.; Lee, K.-H.; Cho, M.-H. Elevated Inorganic Phosphate Stimulates Akt-ERK1/2-Mnk1 Signaling in Human Lung Cells. Am. J. Respir. Cell Mol. Biol. 2006, 35, 528-539. [CrossRef]

129. Wargovich, M.J.; Eng, V.W.; Newmark, H.L. Calcium Inhibits the Damaging and Compensatory Proliferative Effects of Fatty Acids on Mouse Colon Epithelium. Cancer Lett. 1984, 23, 253-258. [CrossRef]

130. Wargovich, M.J.; Eng, V.W.; Newmark, H.L.; Bruce, W.R. Calcium Ameliorates the Toxic Effect of Deoxycholic Acid on Colonic Epithelium. Carcinogenesis 1983, 4, 1205-1207. [CrossRef]

131. Lipkin, M.; Newmark, H. Effect of Added Dietary Calcium on Colonic Epithelial-Cell Proliferation in Subjects at High Risk for Familial Colonic Cancer. N. Engl. J. Med. 1985, 313, 1381-1384. [CrossRef]

132. Chan, J.M.; Pietinen, P.; Virtanen, M.; Malila, N.; Tangrea, J.; Albanes, D.; Virtamo, J. Diet and Prostate Cancer Risk in a Cohort of Smokers, with a Specific Focus on Calcium and Phosphorus (Finland). Cancer Causes Control 2000, 11, 859-867. [CrossRef]

133. Zhu, G.; Chen, C.; Hu, B.; Yuan, D.; Chen, W.; Wang, W.; Su, J.; Liu, Z.; Jiao, K.; Chen, X.; et al. Dietary Phosphorus Intake and Serum Prostate-Specific Antigen in Non-Prostate Cancer American Adults: A Secondary Analysis of the National Health and Nutrition Examination Survey (NHANES), 2003-2010. Asia Pac. J. Clin. Nutr. 2020, 29, 322-333. [CrossRef]

134. Kesse, E.; Boutron-Ruault, M.-C.; Norat, T.; Riboli, E.; Clavel-Chapelon, F. Dietary Calcium, Phosphorus, Vitamin D, Dairy Products and the Risk of Colorectal Adenoma and Cancer among French Women of the E3N-EPIC Prospective Study. Int. J. Cancer 2005, 117, 137-144. [CrossRef] [PubMed]

135. Brinkman, M.T.; Buntinx, F.; Kellen, E.; Dagnelie, P.C.; Van Dongen, M.C.J.M.; Muls, E.; Zeegers, M.P. Dietary Intake of Micronutrients and the Risk of Developing Bladder Cancer: Results from the Belgian Case-Control Study on Bladder Cancer Risk. Cancer Causes Control 2011, 22, 469-478. [CrossRef]

136. Tavani, A.; Bertuccio, P.; Bosetti, C.; Talamini, R.; Negri, E.; Franceschi, S.; Montella, M.; La Vecchia, C. Dietary Intake of Calcium, Vitamin D, Phosphorus and the Risk of Prostate Cancer. Eur. Urol. 2005, 48, 27-33. [CrossRef]

137. Wilson, K.M.; Shui, I.M.; Mucci, L.A.; Giovannucci, E. Calcium and Phosphorus Intake and Prostate Cancer Risk: A 24-y Follow-up Study. Am. J. Clin. Nutr. 2015, 101, 173-183. [CrossRef]

138. Phipps, O.; Brookes, M.J.; Al-Hassi, H.O. Iron Deficiency, Immunology, and Colorectal Cancer. Nutr. Rev. 2021, 79, 88-97. [CrossRef]

139. Xue, X.; Shah, Y.M. Intestinal Iron Homeostasis and Colon Tumorigenesis. Nutrients 2013, 5, 2333-2351. [CrossRef] [PubMed]

140. Verma, S.; Cherayil, B.J. Iron and Inflammation-The Gut Reaction. Met. Integr. Biometal Sci. 2017, 9, 101-111. [CrossRef]

141. Fonseca-Nunes, A.; Jakszyn, P.; Agudo, A. Iron and Cancer Risk-A Systematic Review and Meta-Analysis of the Epidemiological Evidence. Cancer Epidemiol. Biomark. Prev. Publ. Am. Assoc. Cancer Res. Cosponsored Am. Soc. Prev. Oncol. 2014, $23,12-31$. [CrossRef]

142. Roughead, Z.K.F.; Zito, C.A.; Hunt, J.R. Inhibitory Effects of Dietary Calcium on the Initial Uptake and Subsequent Retention of Heme and Nonheme Iron in Humans: Comparisons Using an Intestinal Lavage Method. Am. J. Clin. Nutr. 2005, 82, 589-597. [CrossRef] [PubMed]

143. Pierre, F.; Taché, S.; Petit, C.R.; Van der Meer, R.; Corpet, D.E. Meat and Cancer: Haemoglobin and Haemin in a Low-Calcium Diet Promote Colorectal Carcinogenesis at the Aberrant Crypt Stage in Rats. Carcinogenesis 2003, 24, 1683-1690. [CrossRef] [PubMed]

144. Teucher, B.; Olivares, M.; Cori, H. Enhancers of Iron Absorption: Ascorbic Acid and Other Organic Acids. Int. J. Vitam. Nutr. Res. 2004, 74, 403-419. [CrossRef]

145. Plays, M.; Müller, S.; Rodriguez, R. Chemistry and Biology of Ferritin. Met. Integr. Biometal Sci. 2021, 13, mfab021. [CrossRef] [PubMed]

146. Paganoni, R.; Lechel, A.; Vujic Spasic, M. Iron at the Interface of Hepatocellular Carcinoma. Int. J. Mol. Sci. 2021, 22, 4097. [CrossRef] [PubMed]

147. Siegers, C.P.; Bumann, D.; Trepkau, H.D.; Schadwinkel, B.; Baretton, G. Influence of Dietary Iron Overload on Cell Proliferation and Intestinal Tumorigenesis in Mice. Cancer Lett. 1992, 65, 245-249. [CrossRef]

148. Lund, E.K.; Wharf, S.G.; Fairweather-Tait, S.J.; Johnson, I.T. Increases in the Concentrations of Available Iron in Response to Dietary Iron Supplementation Are Associated with Changes in Crypt Cell Proliferation in Rat Large Intestine. J. Nutr. 1998, 128, 175-179. [CrossRef] [PubMed]

149. Perše, M. Oxidative Stress in the Pathogenesis of Colorectal Cancer: Cause or Consequence? BioMed Res. Int. 2013, 2013, 725710. [CrossRef]

150. Vissers, M.C.M.; Das, A.B. Potential Mechanisms of Action for Vitamin C in Cancer: Reviewing the Evidence. Front. Physiol. 2018, 9, 809. [CrossRef] [PubMed]

151. Ji, L.L.; Gomez-Cabrera, M.-C.; Vina, J. Role of Nuclear Factor KappaB and Mitogen-Activated Protein Kinase Signaling in Exercise-Induced Antioxidant Enzyme Adaptation. Appl. Physiol. Nutr. Metab. Physiol. Appl. Nutr. Metab. 2007, 32, 930-935. [CrossRef] [PubMed]

152. Kramer, H.F.; Goodyear, L.J. Exercise, MAPK, and NF-KappaB Signaling in Skeletal Muscle. J. Appl. Physiol. 2007, 103, 388-395. [CrossRef] 
153. Read, A.D.; Bentley, R.E.; Archer, S.L.; Dunham-Snary, K.J. Mitochondrial Iron-Sulfur Clusters: Structure, Function, and an Emerging Role in Vascular Biology. Redox Biol. 2021, 47, 102164. [CrossRef]

154. Puig, S.; Ramos-Alonso, L.; Romero, A.M.; Martínez-Pastor, M.T. The Elemental Role of Iron in DNA Synthesis and Repair. Met. Integr. Biometal Sci. 2017, 9, 1483-1500. [CrossRef]

155. Eklund, H.; Uhlin, U.; Färnegårdh, M.; Logan, D.T.; Nordlund, P. Structure and Function of the Radical Enzyme Ribonucleotide Reductase. Prog. Biophys. Mol. Biol. 2001, 77, 177-268. [CrossRef]

156. Ruskoski, T.B.; Boal, A.K. The Periodic Table of Ribonucleotide Reductases. J. Biol. Chem. 2021, 297, 101137. [CrossRef] [PubMed]

157. Brookes, M.J.; Boult, J.; Roberts, K.; Cooper, B.T.; Hotchin, N.A.; Matthews, G.; Iqbal, T.; Tselepis, C. A Role for Iron in Wnt Signalling. Oncogene 2008, 27, 966-975. [CrossRef]

158. Aceves, C.; Mendieta, I.; Anguiano, B.; Delgado-González, E. Molecular Iodine Has Extrathyroidal Effects as an Antioxidant, Differentiator, and Immunomodulator. Int. J. Mol. Sci. 2021, 22, 1228. [CrossRef] [PubMed]

159. Smyth, P.P.A. Role of Iodine in Antioxidant Defence in Thyroid and Breast Disease. BioFactors 2003, 19, 121-130. [CrossRef]

160. Zacharski, L.R.; Chow, B.K.; Howes, P.S.; Shamayeva, G.; Baron, J.A.; Dalman, R.L.; Malenka, D.J.; Ozaki, C.K.; Lavori, P.W. Decreased Cancer Risk after Iron Reduction in Patients with Peripheral Arterial Disease: Results from a Randomized Trial. J. Natl. Cancer Inst. 2008, 100, 996-1002. [CrossRef]

161. Wen, C.P.; Lee, J.H.; Tai, Y.-P.; Wen, C.; Wu, S.B.; Tsai, M.K.; Hsieh, D.P.H.; Chiang, H.-C.; Hsiung, C.A.; Hsu, C.Y.; et al. High Serum Iron Is Associated with Increased Cancer Risk. Cancer Res. 2014, 74, 6589-6597. [CrossRef] [PubMed]

162. Cao, H.; Wang, C.; Chai, R.; Dong, Q.; Tu, S. Iron Intake, Serum Iron Indices and Risk of Colorectal Adenomas: A Meta-Analysis of Observational Studies. Eur. J. Cancer Care 2017, 26, e12486. [CrossRef]

163. Chang, V.C.; Cotterchio, M.; Khoo, E. Iron Intake, Body Iron Status, and Risk of Breast Cancer: A Systematic Review and Meta-Analysis. BMC Cancer 2019, 19, 543. [CrossRef]

164. Sawayama, H.; Iwatsuki, M.; Kuroda, D.; Toihata, T.; Uchihara, T.; Koga, Y.; Yagi, T.; Kiyozumi, Y.; Eto, T.; Hiyoshi, Y.; et al. Total Iron-Binding Capacity Is a Novel Prognostic Marker after Curative Gastrectomy for Gastric Cancer. Int. J. Clin. Oncol. 2018, 23, 671-680. [CrossRef] [PubMed]

165. Malya, F.U.; Kadioglu, H.; Hasbahceci, M.; Dolay, K.; Guzel, M.; Ersoy, Y.E. The Correlation between Breast Cancer and Urinary Iodine Excretion Levels. J. Int. Med. Res. 2018, 46, 687-692. [CrossRef] [PubMed]

166. Von Holle, A.; O’Brien, K.M.; Sandler, D.P.; Janicek, R.; Weinberg, C.R. Association Between Serum Iron Biomarkers and Breast Cancer. Cancer Epidemiol. Biomark. Prev. Publ. Am. Assoc. Cancer Res. Cosponsored Am. Soc. Prev. Oncol. 2021, $30,422-425$. [CrossRef]

167. Fan, S.; Li, X.; Zheng, L.; Hu, D.; Ren, X.; Ye, Z. Correlations between the Iodine Concentrations from Dual Energy Computed Tomography and Molecular Markers Ki-67 and HIF-1 $\alpha$ in Rectal Cancer: A Preliminary Study. Eur. J. Radiol. 2017, 96, 109-114. [CrossRef]

168. Hu, M.-J.; He, J.-L.; Tong, X.-R.; Yang, W.-J.; Zhao, H.-H.; Li, G.-A.; Huang, F. Associations between Essential Microelements Exposure and the Aggressive Clinicopathologic Characteristics of Papillary Thyroid Cancer. Biometals 2021, 34, 909-921. [CrossRef] [PubMed]

169. Bong, A.H.L.; Monteith, G.R. Calcium Signaling and the Therapeutic Targeting of Cancer Cells. Biochim. Biophys. Acta Mol. Cell Res. 2018, 1865, 1786-1794. [CrossRef] [PubMed]

170. Prevarskaya, N.; Skryma, R.; Shuba, Y. Calcium in Tumour Metastasis: New Roles for Known Actors. Nat. Rev. Cancer 2011, 11, 609-618. [CrossRef] [PubMed]

171. Groenendyk, J.; Michalak, M. Endoplasmic Reticulum Quality Control and Apoptosis. Acta Biochim. Pol. 2005, 52, $381-395$. [CrossRef]

172. Schrag, J.D.; Bergeron, J.J.; Li, Y.; Borisova, S.; Hahn, M.; Thomas, D.Y.; Cygler, M. The Structure of Calnexin, an ER Chaperone Involved in Quality Control of Protein Folding. Mol. Cell 2001, 8, 633-644. [CrossRef]

173. Berridge, M.J. Inositol Trisphosphate and Calcium Signalling Mechanisms. Biochim. Biophys. Acta 2009, 1793, 933-940. [CrossRef]

174. Chung, F.-Y.; Lin, S.-R.; Lu, C.-Y.; Yeh, C.-S.; Chen, F.-M.; Hsieh, J.-S.; Huang, T.-J.; Wang, J.-Y. Sarco/Endoplasmic Reticulum Calcium-ATPase 2 Expression as a Tumor Marker in Colorectal Cancer. Am. J. Surg. Pathol. 2006, 30, 969-974. [CrossRef]

175. Papp, B.; Launay, S.; Gélébart, P.; Arbabian, A.; Enyedi, A.; Brouland, J.-P.; Carosella, E.D.; Adle-Biassette, H. Endoplasmic Reticulum Calcium Pumps and Tumor Cell Differentiation. Int. J. Mol. Sci. 2020, 21, 3351. [CrossRef] [PubMed]

176. Kozlov, G.; Azeroual, S.; Rosenauer, A.; Määttänen, P.; Denisov, A.Y.; Thomas, D.Y.; Gehring, K. Structure of the Catalytic a(0)a Fragment of the Protein Disulfide Isomerase ERp72. J. Mol. Biol. 2010, 401, 618-625. [CrossRef] [PubMed]

177. Turano, C.; Gaucci, E.; Grillo, C.; Chichiarelli, S. ERp57/GRP58: A Protein with Multiple Functions. Cell. Mol. Biol. Lett. 2011, 16, 539-563. [CrossRef] [PubMed]

178. Abdelkarim, H.; Leschinsky, N.; Jang, H.; Banerjee, A.; Nussinov, R.; Gaponenko, V. The Dynamic Nature of the K-Ras/Calmodulin Complex Can Be Altered by Oncogenic Mutations. Curr. Opin. Struct. Biol. 2021, 71, 164-170. [CrossRef] [PubMed]

179. Villalobo, A.; Berchtold, M.W. The Role of Calmodulin in Tumor Cell Migration, Invasiveness, and Metastasis. Int. J. Mol. Sci. 2020, 21, 765. [CrossRef] [PubMed]

180. Kelly, M.G.; Winkler, S.S.; Lentz, S.S.; Berliner, S.H.; Swain, M.F.; Skinner, H.G.; Schwartz, G.G. Serum Calcium and Serum Albumin Are Biomarkers That Can Discriminate Malignant from Benign Pelvic Masses. Cancer Epidemiol. Biomark. Prev. Publ. Am. Assoc. Cancer Res. Cosponsored Am. Soc. Prev. Oncol. 2015, 24, 1593-1598. [CrossRef] [PubMed] 
181. Wulaningsih, W.; Sagoo, H.K.; Hamza, M.; Melvin, J.; Holmberg, L.; Garmo, H.; Malmström, H.; Lambe, M.; Hammar, N.; Walldius, G.; et al. Serum Calcium and the Risk of Breast Cancer: Findings from the Swedish AMORIS Study and a Meta-Analysis of Prospective Studies. Int. J. Mol. Sci. 2016, 17, 1487. [CrossRef]

182. Huang, P.; Lan, M.; Peng, A.-F.; Yu, Q.-F.; Chen, W.-Z.; Liu, Z.-L.; Liu, J.-M.; Huang, S.-H. Serum Calcium, Alkaline Phosphotase and Hemoglobin as Risk Factors for Bone Metastases in Bladder Cancer. PLoS ONE 2017, 12, e0183835. [CrossRef] [PubMed]

183. Xu, Q.-H.; Zhu, P.-W.; Li, B.; Shi, W.-Q.; Lin, Q.; Min, Y.-L.; Ge, Q.-M.; Yuan, Q.; Shao, Y. Carbohydrate Antigen-125, Calcium, and Hemoglobin as Predictive Clinical Indicator for Ocular Metastasis in Male Liver Cancer Patients. Biosci. Rep. 2020, 40, BSR20194405. [CrossRef] [PubMed]

184. Rohatgi, A. WebPlotDigitizer: Version 4.5. 2021. Available online: https://automeris.io/WebPlotDigitizer/ (accessed on 21 February 2022).

185. Erem, S.; Razzaque, M.S. Dietary Phosphate Toxicity: An Emerging Global Health Concern. Histochem. Cell Biol. 2018, 150, 711-719. [CrossRef] [PubMed]

186. Tulchinsky, T.H. Micronutrient Deficiency Conditions: Global Health Issues. Public Health Rev. 2010, 32, 243-255. [CrossRef]

187. Dwyer, J.T.; Woteki, C.; Bailey, R.; Britten, P.; Carriquiry, A.; Gaine, P.C.; Miller, D.; Moshfegh, A.; Murphy, M.M.; Smith Edge, M. Fortification: New Findings and Implications. Nutr. Rev. 2014, 72, 127-141. [CrossRef] [PubMed]

188. Best, C.; Neufingerl, N.; Del Rosso, J.M.; Transler, C.; van den Briel, T.; Osendarp, S. Can Multi-Micronutrient Food Fortification Improve the Micronutrient Status, Growth, Health, and Cognition of Schoolchildren? A Systematic Review. Nutr. Rev. 2011, 69, 186-204. [CrossRef]

189. Rowe, L.A. Addressing the Fortification Quality Gap: A Proposed Way Forward. Nutrients 2020, 12, 3899. [CrossRef]

190. Dewi, N.U.; Mahmudiono, T. Effectiveness of Food Fortification in Improving Nutritional Status of Mothers and Children in Indonesia. Int. J. Environ. Res. Public Health 2021, 18, 2133. [CrossRef] [PubMed]

191. Das, J.K.; Salam, R.A.; Kumar, R.; Bhutta, Z.A. Micronutrient Fortification of Food and Its Impact on Woman and Child Health: A Systematic Review. Syst. Rev. 2013, 2, 67. [CrossRef] [PubMed] 